\title{
Expression of Tenascin in the Developing and Adult Cerebellar Cortex
}

\author{
Susanne Bartsch, ${ }^{1}$ Udo Bartsch, ${ }^{1}$ Ulrich Dörries, ${ }^{1}$ Andreas Faissner, ${ }^{2}$ Andreas Weller, ${ }^{3}$ Peter Ekblom, ${ }^{4}$ and \\ Melitta Schachner'
}

'Department of Neurobiology, Swiss Federal Institute of Technology, Hönggerberg, 8093 Zürich, Switzerland, ${ }^{2}$ Department of Neurobiology, University of Heidelberg, 69 Heidelberg, Germany, ${ }^{3}$ Hans-Spemann-Laboratorium, MPI Immunbiologie, 78 Freiburg, Germany, and ${ }^{4}$ Department of Animal Physiology, Uppsala University, S-75122, Uppsala, Sweden

\begin{abstract}
Since tenascin may influence neuronal cell development, we studied its expression pattern using immunocytochemistry, in situ hybridization, Northern blot analysis, and immunochemistry in the developing and adult mouse cerebellar cortex. Tenascin immunoreactivity was detectable in all layers of the developing cerebellar cortex. In the external granular layer, only the radially oriented processes of Golgi epithelial cells were immunoreactive, whereas the densely packed cell bodies were immunonegative. Tenascin was hardly detectable at contact sites between migrating granule cells and processes of Golgi epithelial cells. Axons of granule celis in the molecular layer were immunoreactive, whereas their cell bodies in the internal granular layer lacked detectable levels of tenascin. By in situ hybridization, only Golgi epithelial cells and astrocytes of the internal granular layer and prospective white matter, but not nerve cells, could be shown to synthesize detectable levels of tenascin mRNA in the developing mouse cerebellar cortex. Thus, tenascin in the cerebellar cortex seems to be a glia-derived molecule that becomes adsorbed to neuronal surfaces in a topographically restricted pattern in situ.
\end{abstract}

Levels of tenascin protein and mRNA decreased significantly with increasing age. In the adult, tenascin immunoreactivity was weak and mainly restricted to the molecular layer and tenascin mRNA was confined to Golgi epithelial cells, indicative for a functional heterogeneity in differentiated cerebellar astrocytes. Quantitative immunoblot analysis revealed that the 225 and 240 kDa components of tenascin were developmentally downregulated at a faster rate than the 190 and $200 \mathrm{kDa}$ components, corresponding to the faster downregulation of the 8 kilobase $(\mathrm{kb})$ mRNA species compared to the $6 \mathrm{~kb}$ mRNA species as revealed by Northern blot analysis. These observations indicate a differentially regulated expression of the tenascin components.

We hypothesize that glia-derived tenascin modifies the functional properties of nerve cell surfaces and that tenascin is involved in such different morphogenetic events as neurite growth and oligodendrocyte distribution.

\footnotetext{
Received July 23, 1991; revised Oct. 3, 1991 ; accepted Oct. 8, 1991.

We thank M. Keggenhoff and J. Casado for excellent technical assistance; Drs. Iris Kramer, Rudolf Martini, and Joanne Taylor for comments on the manuscript; and Ciba Geigy (Basel), Kommission zur Förderung der wissenschaftlichen Forschung; and Deutsche Forschungsgemeinschaft (SFB 317) for support.

Correspondence should be addressed to Udo Bartsch, Neurobiologie, ETHHönggerberg (HPM), CH-8093 Zürich, Switzerland.

Copyright (C) 1992 Society for Neuroscience $0270-6474 / 92 / 120736-14 \$ 05.00 / 0$
}

Cell proliferation and migration, axonal and dendritic growth, synaptogenesis, cell death, and synapse elimination are the principal events leading to the formation of the CNS (for reviews, see Jacobson, 1978; Lund, 1978; Cowan, 1982; Purves and Lichtman, 1985). Many of these developmental events have been studied in the avian and mammalian cerebellar cortex (see, e.g., Mugnaini and Forstronen, 1967; Larramendi, 1969; Rakic, 1971; Altman, 1982), because of its geometrically simple, laminated structure, and its few and identifiable neuronal cell types. Moreover, much of cerebellar histogenesis in rodents takes place postnatally, such as the production of the majority of interneurons, outgrowth of their processes, or establishment of their synapses (Miale and Sidman, 1961; Fujita, 1967; Altman, 1982), making the cerebellum more easily accessible to experimental manipulations. The migration of young postmitotic granule cells from the external to the internal granular layer, for instance, has been studied in great detail in this brain region because it exemplifies a paradigmatic neuron-glia interaction, in which migrating granule cells use the processes of Golgi epithelial cells, the Bergmann fibers, for guidance (Rakic, 1971; Hatten et al., 1984; Edmondson and Hatten, 1987).

With the aim to understand the molecular mechanisms underlying the histogenesis of the nervous system, several recognition molecules have been identified and functionally characterized (for reviews, see Edelman, 1986; Jessell, 1988; Schachner et al., 1990). The neural cell adhesion molecule (NCAM), for instance, is involved in neurite growth and neurite fasciculation (Fischer et al., 1986; Neugebauer et al., 1988; Smith et al., 1990). Similarly, the murine neural recognition molecule Ll (Rathjen and Schachner, 1984) and the related molecules $\mathrm{Ng}-\mathrm{CAM}, \mathrm{G} 4$, and 8D9 in the chicken support neurite growth on the surface of Schwann cells (Bixby et al., 1988; Seilheimer and Schachner, 1988), axons, and astrocytes (Chang et al., 1987; Drazba and Lemmon, 1990; Smith et al., 1990; Saad et al., 1991) and mediate axon fasciculation (Fischer et al., 1986; Hoffman et al., 1986; Rathjen et al., 1987). Interestingly, migration of cerebellar granule cells can be inhibited by antibodies to different recognition molecules, including $\mathrm{L} 1$ (Lindner et al., 1983, 1986) and Ng-CAM (Chuong et al., 1987), the adhesion molecule on glia (AMOG; Antonicek et al., 1987), and N-CAM (Lindner et al., 1986; Chuong et al., 1987).

Yet other recognition molecules, the $\mathrm{J} 1$ glycoproteins, have been shown to mcdiatc ncuron-astrocyte recognition (Kruse et al., 1985). The J1 glycoproteins appear as four components (J1-160, J1-180, J1-200, and J1-220; Kruse et al., 1985) with apparent molecular weights of $160,180,200$, and $220 \mathrm{kDa}$, 
respectively. J1-200 and J1-220 have been shown to be immunochemically and structurally related to tenascin in the chicken (Chiquet-Ehrismann et al., 1986), which is identical to cylotactin (Grumet et al., 1985) and have therefore been called $\mathrm{J} 1 /$ tenascin pending sequence analysis (Faissner et al., 1988). Recently, the sequencing of $\mathrm{J} 1 /$ tenascin-specific cDNA clones from a mouse brain cDNA library (U. Dörries and M. Schachner, unpublished observations) has shown no marked difference to the mouse tenascin cDNA sequence determined from cDNA clones isolated from a mouse fibroblast cDNA library (Weller et al., 1991). J1/tenascin will therefore be referred to as tenascin in the future. A human homolog to tenascin, called hexabrachion, has also been described (Erickson and Iglesias, 1984; for review, see Erickson and Bourdon, 1989). These molecules have been implicated in a variety of different morphogenetic events. Antibodies to tenascin interfere with granule cell migration in chicken (Chuong et al., 1987) and mouse (K. Husmann, A. Faissner, and M. Schachner, unpublished observations), inhibit the spreading of neural crest cells (Tan et al., 1987; Halfter et al., 1989), influence neural crest cell migration (Tan et al., 1987; Bronner-Fraser, 1988; Mackie et al., 1988; Halfter et al., 1989; Stern et al., 1989), and have repulsive properties for different CNS nerve cell types (Faissner and Kruse, 1990). Tenascin and proteoglycans binding to it demarcate barrel field boundaries in the developing somatosensory cortex of mice (Crossin et al., 1989; Steindler et al., 1989a,b). This patterned distribution of extracellular matrix molecules in the somatosensory cortex becomes detectable not before thalamic afferents have established their principal projection pattern (Jhaveri et al., 1991). Furthermore, because of the lesion-induced increase in expression of tenascin in the chick and mouse sciatic nerve (Daniloff et al., 1989; Martini et al., 1990) and at the neuromuscular junction (Sanes et al., 1986; for review, see Sanes et al., 1990), the molecule has been suggested to play a crucial role in regeneration in the PNS. This notion is supported by the observations that tenascin levels are not significantly increased after transcction of the nonregenerative adult mouse optic nerve (U. Bartsch, S. Bartsch, and M. Schachner, unpublished observations) and that substrate-bound tenascin has been shown to promote neurite growth in vitro (Chiquet, 1989; Wehrle and Chiquet, 1990; Lochter et al., 1991).

To gain further insight into the possibly multiple morphogenetic functions of tenascin during the histogenesis of the mouse cerebellar cortex, we have now studied its cellular localization at different ages at the light and electron microscopic level. Additionally, since tenascin is a secreted glycoprotein (Kruse et al., 1985), we investigated its cellular source by in situ hybridization. Finally, Northern blot analysis and quantitative immunoblot analysis were carried out to analyze the developmental expression pattern of the tenascin isoforms.

\section{Materials and Methods}

Animals. NMRI mice were used at $0,2,6,7,9,14,21$, and $28 \mathrm{~d}$ of age. Adult mice were at least 6 months old.

Antibodies. Purification of tenascin and preparation and characterization of the two monoclonal rat $(\mathrm{J} 1 / \mathrm{tn} 1$ and $\mathrm{J} 1 / \mathrm{tn} 2$, previously designated 576 and 578 , respectively) and polyclonal (pJ1/tn) rabbit antibodies to tenascin have been described (Steindler et al., 1989a; Stern et al., 1989; Faissner and Kruse, 1990; Lochter et al., 1991). Production and characterization of polyclonal rabbit antibodies to the neural recognition molecule L1 have also been described (Rathjen and Schachner, 1984). For the immunocytochemical detection of primary antibodies, fluorescein isothiocyanate (FITC)-conjugated swine anti-rabbit (Dakopatts) or goat anti-rat (Dianova) IgG antibodies were used at a dilution of 1:100. Protein A (Sigma) and goat anti-rat IgG antibodies (Dianova) coupled to horseradish peroxidase (HRP) were used for indirect immunoelectron microscopy at dilutions of $1: 25$ and 1:500, respectively. To visualize digoxigenin-labeled cRNA probes by in situ hybridization, alkaline phosphatase-coupled antibodies to digoxigenin (Boehringer Mannheim) were used at a dilution of 1:500. 125 I-labeled protein A and sheep anti-rat IgG antibodies (Amersham) were used for quantitative immunoblot analysis.

Indirect immunofluorescence microscopy. Indirect immunofluorescence microscopy was carried out as described (Bartsch et al., 1989, 1990). In brief, 14- $\mu \mathrm{m}$-thick parasagittal cryostat sections from fresh frozen cerebella were mounted on poly-L-lysine-coated coverslips, air dried, and incubated with phosphate-buffered saline, pH 7.3 (PBS), containing $1 \%$ bovine serum albumin (BSA). Sections were incubated with primary antibodies for approximately $2 \mathrm{hr}$, washed, incubated with secondary antibodies for $45 \mathrm{~min}$, and washed again, all at room temperature.

Indirect immunoelectron microscopy. Indirect immunoelectron microscopy was carried out as described (Martini and Schachner, 1986; Bartsch et al., 1989, 1990). In brief, brains of mice from different ages were fixed by perfusion using 0.12 м Palay buffer $(\mathrm{pH}$ 7.3; Palay and Chan-Palay, 1974) containing either $4 \%$ paraformaldehyde or $4 \%$ paraformaldehyde and $0.25 \%$ glutaraldehyde. Alternatively, brains were fixed by immersion in these fixatives. Parasagittal vibratome sections, 100 $\mu \mathrm{m}$ thick, from mouse cerebella were first incubated overnight in PBS containing $1 \%$ BSA and then with primary antibodies for $1-2 \mathrm{~d}$, all at $4^{\circ} \mathrm{C}$. After sections were washed in PBS containing $0.1 \%$ BSA, they were incubated with HRP-coupled protein A or HRP-coupled goat anti-rat $\mathrm{IgG}$ antibodies for at least $4 \mathrm{hr}$ at room temperature. Sections were thoroughly washed, fixed with $1 \%$ glutaraldehyde in $0.01 \mathrm{~m}$ phosphate buffer (pH 7.3), washed again, immersed in $0.02 \% 3,3^{\prime}$-diaminobenzidine $4 \mathrm{HCl}$ (DAB; Sigma) in $0.04 \mathrm{M}$ Tris buffer (pH 7.6) for $30 \mathrm{~min}$, followed by an incubation in the same DAB solution containing $0.01 \%$ $\mathrm{H}_{2} \mathrm{O}_{2}$ for up to $60 \mathrm{~min}$. After postfixation with $2 \% \mathrm{OsO}_{4}$ for $30 \mathrm{~min}$, vibratome sections were embedded in Spurr and ultrathin sections were analyzed with a Zeiss EM 10 .

Nucleic acid probes for in situ hybridization and Northern blot analysis. To isolate a cDNA clone as a probe for in situ hybridization and Northern blot analysis, a 1.107 kilobase (kb) fragment of the cDNA clone M20/1 coding for mouse tenascin from fibroblasts (Weller et al., 1991) was used to screen a cDNA library from 8-d-old mouse brain (Tacke et al., 1987). A tenascin-specific 2 kb cDNA clone, $\lambda \mathrm{JT} 1$, was isolated and the insert was cloned into the EcoRI site of pBluescript KS (Stratagene), giving rise to plasmid $\mathrm{pJT} 1$, and sequenced (U. Dörries and $M$. Schachner, unpublished observations). The sequence of the insert starts at position 2475 and ends at position 5841 of the published mouse tenascin cDNA sequence (Weller et al., 1991) and does not include the alternatively spliced fibronectin type III repeats from position 3340 to 4704. Antisense and sense cRNA probes were generated by transcribing the pJT1 plasmid, linearized with Xbal and Xhol, from the T3 and T7 promotors, respectively.

${ }^{35} \mathrm{~S}$ - and ${ }^{32} \mathrm{P}$-labeled cRNA probes were generated using $50 \mu \mathrm{Ci} \alpha^{35} \mathrm{~S}$ UTP (Amersham; $1000 \mathrm{Ci} / \mathrm{mmol}$ ) or $50 \mu \mathrm{Ci} \alpha^{32} \mathrm{P}$-CTP (Amersham; 400 $\mathrm{Ci} / \mathrm{mmol}$ ) in a reaction mixture containing $0.5 \mathrm{~mm}$ each ATP, GTP, and TTP; $12 \mu \mathrm{M}$ UTP; $1 \mu \mathrm{g}$ of linearized plasmid DNA; $10 \mathrm{~mm} \mathrm{di-}$ thiothreitol (DTT); T3/T7-transcription buffer [GIBCO/Bethesda Research Labs. (BRL)] 1 U RNasin (Boehringer Mannheim); and $50 \mathrm{U}$ T3 or T7 RNA polymerase (GIBCO/BRL). Transcripts were purified by phenol/chloroform extraction followed by ethanol precipitation. Digoxigenin-labeled probes were generated according to the manufacturer's recommendations using the RNA Labeling Kit (Boehringer Mannheim). Both ${ }^{35} \mathrm{~S}$ - and digoxigenin-labeled probes were digested under alkaline conditions to obtain an average fragment length of approximately 250 nucleotides. The size distribution of these fragments was verified by separating aliquots of the hydrolyzed samples on a $1.8 \%$ formaldehyde/agarose gel and blotting onto a nylon membrane (Pall Biodyne $\Lambda$ ). ${ }^{35}$ S-labeled probes were detected by autoradiography; digoxigenin-labeled probes by alkaline phosphatase-coupled antibodies to digoxigenin provided in the Nucleic Acid Detection Kit (Boehringer Mannheim) following the manufacturer's instructions. Antisense and sense transcripts of ${ }^{35} \mathrm{~S}$ - and digoxigenin-labeled probes were checked for their relative detection sensitivities by hybridizing them to dot blots containing serial dilutions of plasmid pJT 1 followed by autoradiograph- 
13

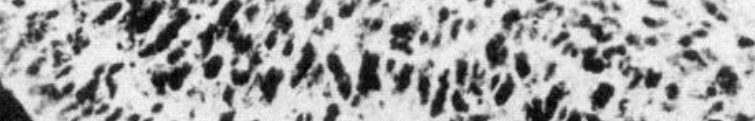

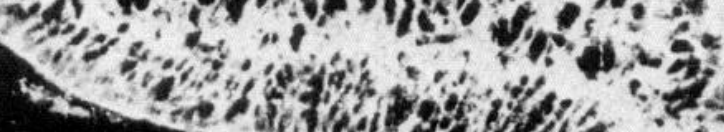

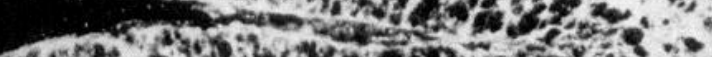

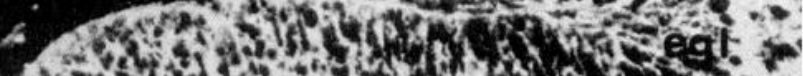

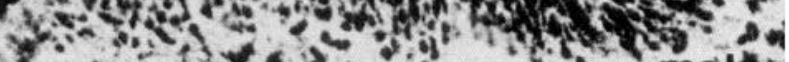

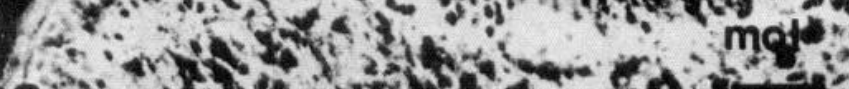

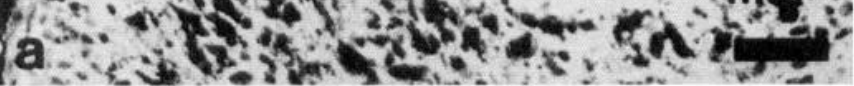
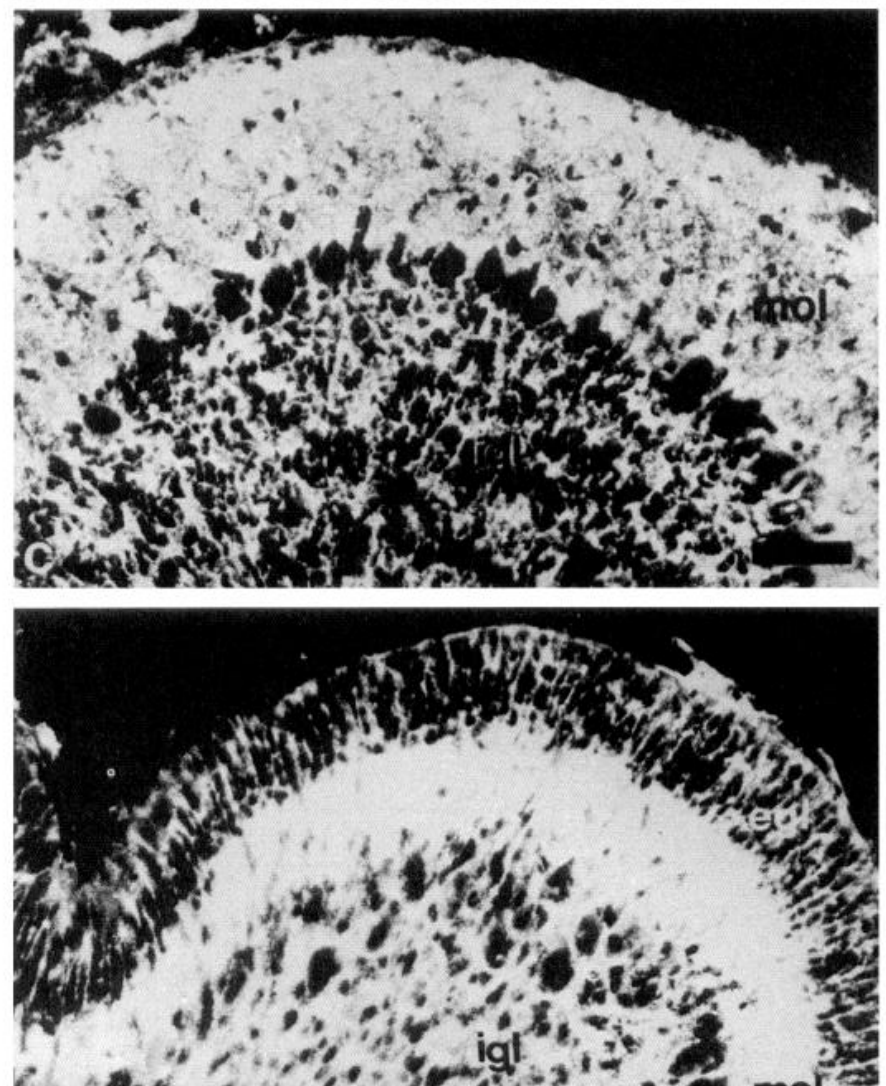

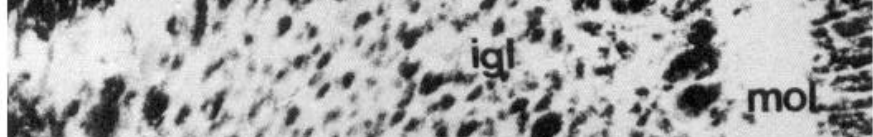
(E)

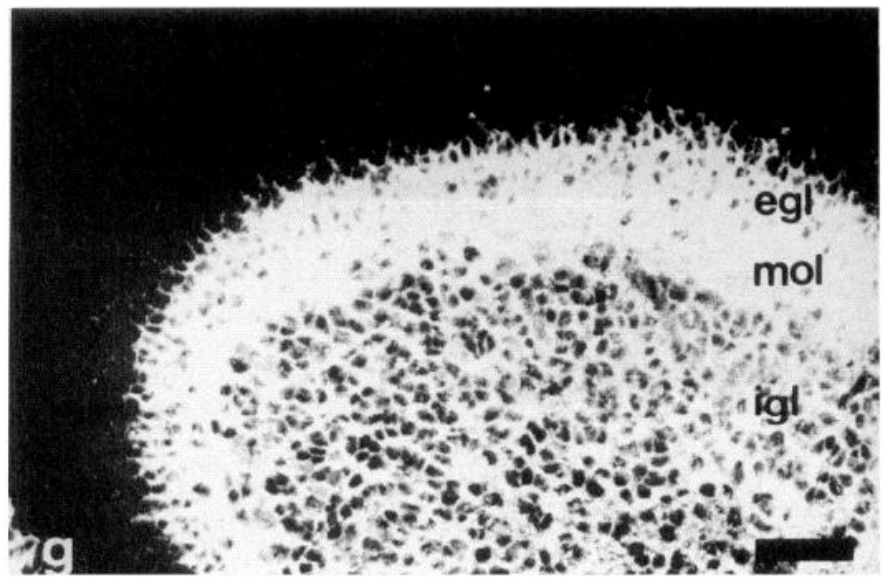

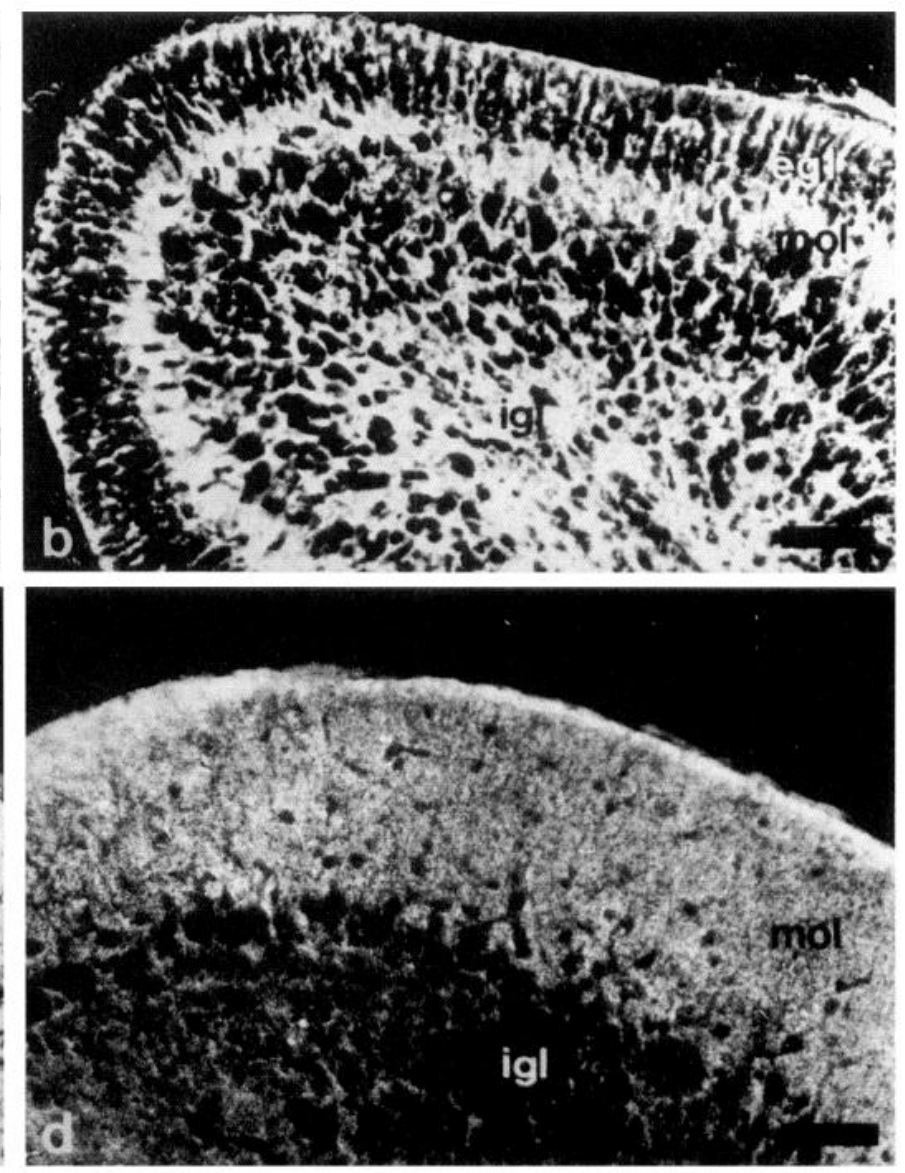
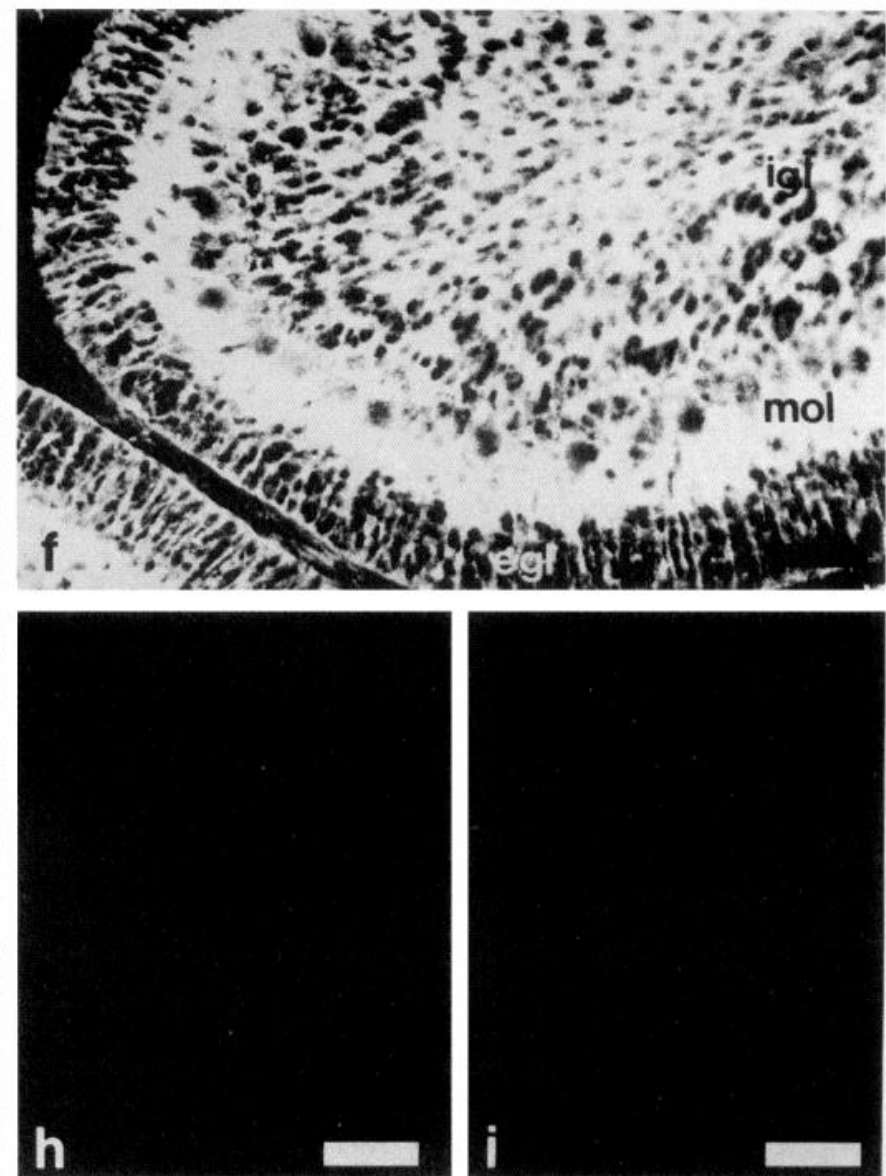
ical or immunochemical quantification. In addition, ${ }^{35}$ S-labeled antisense and sense probes were analyzed for comparable levels of incorporated radioactivity in a scintillation counter.

In situ hybridization. Cryostat sections, $10 \mu \mathrm{m}$ thick, of fresh-frozen mouse cerebella were thaw mounted onto 3-aminopropyltriethoxy-silane (Sigma) coated and fixed with $4 \%$ paraformaldehyde in PBS for 30 min. Alternatively, vibratome sections, $40 \mu \mathrm{m}$ thick, were prepared from tissue fixed in PBS containing 4\% paraformaldehyde. After washing in PBS, sections were stored for further treatment in $70 \%$ ethanol at $4^{\circ} \mathrm{C}$. Before prehybridization, sections were washed twice in distilled water, treated with $0.1 \mathrm{M} \mathrm{HCl}$ for $10 \mathrm{~min}$, washed twice with PBS, and incubated in $0.1 \mathrm{M}$ triethanolamine, $\mathrm{pH} 8.0$, containing $0.25 \%$ acetic anhydride for $20 \mathrm{~min}$. Sections were then washed twice in PBS, dehydrated in an ascending alcohol series, and air dried. Prehybridization was performed overnight at $37^{\circ} \mathrm{C}$ in a humidified chamber with prehybridization buffer containing $50 \%$ formamide, $25 \mathrm{~mm}$ EDTA, $50 \mathrm{~mm}$ Tris $\mathrm{HCl}$ (pH 7.6), $2.5 \times$ Denhardt's solution, $0.25 \mathrm{mg} / \mathrm{ml} t$ RNA (Boehringer Mannheim), and $20 \mathrm{~mm} \mathrm{NaCl}$. Hybridization was carried out overnight at $55^{\circ} \mathrm{C}$ with different concentrations of the RNA probes in hybridization buffer containing $50 \%$ formamide, $20 \mathrm{mM}$ Tris $\cdot \mathrm{HCl}(\mathrm{pH} 7.5), 1 \mathrm{~mm}$ EDTA, $1 \times$ Denhardt's solution, $0.5 \mathrm{mg} / \mathrm{ml} t \mathrm{RNA}, 0.1 \mathrm{mg} / \mathrm{ml}$ polyA RNA (Sigma), 0.1 m DTT (Sigma), and 10\% dextran sulfate (Sigma). For ${ }^{35} \mathrm{~S}$-labeled transcripts, concentrations of antisense and sense probes were between 4000 and $20,000 \mathrm{cpm} / \mu$ l hybridization buffer. Digoxigenin-labeled transcripts were used at concentrations of approximately $200 \mathrm{pg} / \mu \mathrm{l}$ hybridization buffer. After hybridization, sections were washed twice in $30 \mathrm{~mm} \mathrm{NaCl}$ and $3 \mathrm{~mm} \mathrm{Na}$-citrate (pI 7.0 ; SSC) at $55^{\circ} \mathrm{C}$ for $30 \mathrm{~min}$ each and three times for $1.5 \mathrm{hr}$ each in SSC containing 50\% formamide at $55^{\circ} \mathrm{C}$

Sections hybridized with ${ }^{35}$-labeled probes were then washed with SSC, air dried after being exposed to an ascending alcohol series, and dipped in NTB2 photo emulsion (Kodak) that had been melted at $45^{\circ} \mathrm{C}$ and diluted 1:2 in distilled water. Slides were exposed for a period of 5-18 d at $4^{\circ} \mathrm{C}$, developed for $2 \mathrm{~min}$ with D1 9 developer (Kodak), washed in distilled water, fixed for $5 \mathrm{~min}$, washed in distilled water, and air dried.

Sections hybridized with digoxigenin-labeled probes were washed in SSC and equilibrated with buffer $1(100 \mathrm{~mm}$ Tris $\cdot \mathrm{HCl}, 150 \mathrm{~mm} \mathrm{NaCl}$, $\mathrm{pH} 7.5$ ) for $10 \mathrm{~min}$, followed by incubation in modified buffer $2[1 \%$ Boehringer blocking reagent, $0.5 \%$ BSA fraction V (Sigma) in buffer 1] for $30 \mathrm{~min}$ and incubation with alkaline phosphatase-coupled antibodies to digoxigenin at a dilution of 1:500 in modified buffer 2 overnight at room temperature. Sections were then washed twice for $15 \mathrm{~min}$ in buffer 1, equilibrated for $2 \mathrm{~min}$ in buffer $3(100 \mathrm{mM}$ Tris $\cdot \mathrm{HCl}, 100 \mathrm{~mm}$ $\mathrm{NaCl}, 50 \mathrm{~mm} \mathrm{MgCl}, \mathrm{pH} 9.5$ ), and developed overnight in the dark with buffer 3, composed of $0.34 \mathrm{mg} / \mathrm{ml}$ 4-nitroblue tetrazolium chloride (Sig$\mathrm{ma}$ ), $0.175 \mathrm{mg} / \mathrm{ml} \mathrm{5-bromo-4-chloro-3-indolylphosphate} \mathrm{(Sigma),} \mathrm{and}$ $0.25 \mathrm{mg} / \mathrm{ml}$ levamisol (Sigma). Development was stopped by washing with buffer 4 ( $10 \mathrm{~mm}$ Tris $\cdot \mathrm{HCl}, 1 \mathrm{~mm}$ EDTA, $\mathrm{pH} 8.0)$. Cryostat sections on glass slides were air dried and mounted. Vibratome sections were embedded in Spurr and sections $3 \mu \mathrm{m}$ thick were prepared.

Specificity of the hybridization signal was verified by using antisense and sense probes of comparable specific activity and comparable hybridization signal intensity as determined in dot blots. Antisense and sense probes werc hybridized under identical conditions.

RNA isolation and Northern blot analysis. Total RNA from cerebella of neonatal, 7- and 14-d-old, and adult mice was isolated employing the guanidinium-isothiocyanate (GTC) method as described (Chomczynski and Sacchi, 1987; Pagliusi et al., 1989). After isopropanol precipitation and resolubilization in a small volume of diethylpyrocarbonate (DEPC)-treated water, RNA was diluted in $500 \mathrm{mM} \mathrm{NaCl}$ $10 \mathrm{~mm}$ Tris $\cdot \mathrm{HCl}(\mathrm{pH} 7.2), 0.1 \mathrm{~mm}$ EDTA, and $0.2 \%$ SDS and incubated with oligo-dT-cellulose (type 7 , Pharmacia) overnight. Oligo-dT-cel- lulose was washed three times in $100 \mathrm{~mm} \mathrm{NaCl}, 10 \mathrm{~mm}$ Tris $\cdot \mathrm{HCl}(\mathrm{pH}$ 7.2), $0.1 \mathrm{mM}$ EDTA, and $0.2 \% \mathrm{SDS}$, and polyA ${ }^{+}$RNA was eluted with $10 \mathrm{~mm}$ Tris $\cdot \mathrm{HCl}$ (pH 7.2), $0.1 \mathrm{~mm}$ EDTA, and $0.2 \%$ SDS followed by ethanol precipitation and resuspension in DEPC-treated water.

PolyA $^{+}$RNA of different developmental stages and RNA marker (RNA ladder, GIBCO/BRL) were subjected to electrophoresis on a $0.8 \%$ formaldehyde/agarose gel and subsequently transferred to a Hybond-N membrane (Amersham) in $20 \times \mathrm{SSC}$. After baking for $2 \mathrm{hr}$ at $80^{\circ} \mathrm{C}$, the amount of RNA transferred and bound to the membrane was checked by methylene blue staining as described by Maniatis et al. (1982). Positions of marker bands were marked on the filter. Following a prehybridization for $2 \mathrm{hr}$ at $55^{\circ} \mathrm{C}$, the membrane was hybridized overnight using a tenascin-specific ${ }^{32} \mathrm{P}$-labeled antisense cRNA probe in hybridization buffer ( $5 \times \mathrm{SSC} ; 2.5 \times$ Denhardt's solution; $50 \mathrm{mM} \mathrm{Na} \mathrm{PO}_{4}, \mathrm{pH}$ $6.5 ; 0.1 \%$ SDS; $1 \mathrm{~mm}$ EDTA; $200 \mathrm{mg} / \mathrm{ml}$ salmon sperm DNA; $50 \%$ formamide) at $55^{\circ} \mathrm{C}$. Subsequently the filter was washed three times at $68^{\circ} \mathrm{C}$ in $0.1 \times \mathrm{SSC} / 0.1 \%$ SDS for $20 \mathrm{~min}$ and then exposed to $\mathrm{x}$-ray film (Kodak XAR-5). Size estimation of tenascin mRNA bands as revealed by autoradiography was performed by comparison with the position of marker bands.

Immunoblot analysis. Quantitative immunoblot analysis (Martini et al., 1990) was carried out on a crude membrane fraction from fresh cerebellar tissue (Rathjen and Schachner, 1984). Protein concentrations were determined according to Lowry using BSA as standard (Lowry et al., 1951). Membrane proteins ( $250 \mu \mathrm{g} /$ lane) were separated by SDSPAGE in $4-10 \%$ gradient gels (Laemmli, 1970) and transferred to nitrocellulose filters (Faissner et al., 1988). Filters were incubated for 3 $\mathrm{hr}$ at room temperature in PBS containing $10 \%(\mathrm{w} / \mathrm{v}) \mathrm{BSA}$ and $0.05 \%$ $\mathrm{NaN}_{3}$ and then for $18 \mathrm{hr}$ at room temperature with $6 \mu \mathrm{g} / \mathrm{ml}$ polyclonal or $20 \mu \mathrm{g} / \mathrm{ml}$ monoclonal antibodies to tenascin in PBS containing $0.5 \%$ $(\mathrm{w} / \mathrm{v})$ Tween 20 and $1 \mathrm{mg} / \mathrm{ml}$ BSA. Filters were washed five times in PBS containing $0.5 \%(\mathrm{w} / \mathrm{v})$ Tween 20 and incubated for $2 \mathrm{hr}$ at room temperature with ${ }^{125} \mathrm{I}$-labeled protein A (Amersham; $30 \mathrm{mCi} / \mathrm{mg}, 150$ $\mathrm{nCi} / \mathrm{ml}$ ) for the polyclonal antibodies and ${ }^{125} \mathrm{I}$-labeled sheep antibodies to rat IgG (Amersham; $5-20 \mu \mathrm{Ci} / \mu \mathrm{g} \mathrm{IgG,} 250 \mathrm{nCi} / \mathrm{ml}$ ) for the monoclonal antibodies. After washing five times in PBS containing $0.5 \%(\mathrm{w} / \mathrm{v})$ Tween 20 , nitrocellulose filters were processed for autoradiography (Faissner et al., 1988).

For quantitative analysis, immunoreactive bands were localized autoradiographically. The filter areas carrying the $190 / 200 \mathrm{kDa}$ and $225 /$ $240 \mathrm{kDa}$ tenascin isoform doublets were cut out, and bound radioactivities were separately quantified in a gamma-scintillation counter. The total radioactivity for each lane was determined by summing up the radioactivities from individual filter areas. The highest value determined in the developmental series was set to $100 \%$, and individual values obtained within an experiment containing the developmental series were expressed as percentage fraction of the maximal activity. At least three independent experiments were carried out for each developmental series. The amount of tenascin present in the filter areas was estimated in the same experiment by comparison with a standard calibration curve obtained by quantitative immunoblot analysis of purified tenascin under conditions identical to those for analysis of membrane proteins. Values are given as percentage of the total protein resolved in the lane.

\section{Results}

Immunofluorescence microscopic localization of tenascin in developing and adult mouse cerebellar cortex

Tenascin was detectable at high levels in all layers of the cerebellar cortex from birth up to the third postnatal week by indirect

Figure 1. Immunofluorescence localization of tenascin in the cerebellar cortex of mice at different ages. The distribution of tenascin was analyzed by indirect immunofluorescence microscopy in parasagittal sections of the cerebellar cortex of neonatal $(a), 7-\mathrm{d}$-old $(b, e, f), 14-\mathrm{d}-\mathrm{old}(c)$, and adult $(d)$ mice using polyclonal antibodies $(a-d)$ and the monoclonal antibodies $\mathrm{J} 1 / \operatorname{tn} 2(e)$ and $\mathrm{J} 1 / \operatorname{tn} 1(f)$. In young animals $(a-c)$, tenascin is strongly expressed in all layers, whereas in the adult $(d)$ only weak immunoreactivity is detectable, mainly associated with the molecular layer $(m o l)$. In the external granular layer $(e g l)$ of neonatal and 7-d-old animals, radially oriented immunoreactive structures are visible, corresponding to processes of Golgi epithelial cells $(a, b)$. The developing molecular layer $(\mathrm{mol})$ and the internal granular layer $(i g l)$ are strongly stained by polyclonal tenascin antibodies $(a, b)$. Note that the staining pattern obtained with the two monoclonal antibodies $\mathrm{J} 1 / \operatorname{tn} 2(e)$ and $\mathrm{J} 1 / \mathrm{tn} 1(f)$ in the 7 -d-old cerebellar cortex is identical to that obtained with the polyclonal antibodies $(b)$. For comparison, a 7-d-old mouse cerebellum was stained with polyclonal antibodies to $\mathrm{Ll}(\mathrm{g})$. L1 is strongly expressed in the developing molecular layer, but is also detectable in the internal part of the external granular layer and throughout the internal granular layer $(g)$. In the negative controls, primary antibodies were omitted and neither FITC-conjugated swine anti-rabbit $(h)$ nor FITC-conjugated goat anti-rat $(i)$ antibodies showed any staining. Scale bars, $50 \mu \mathrm{m}$. 


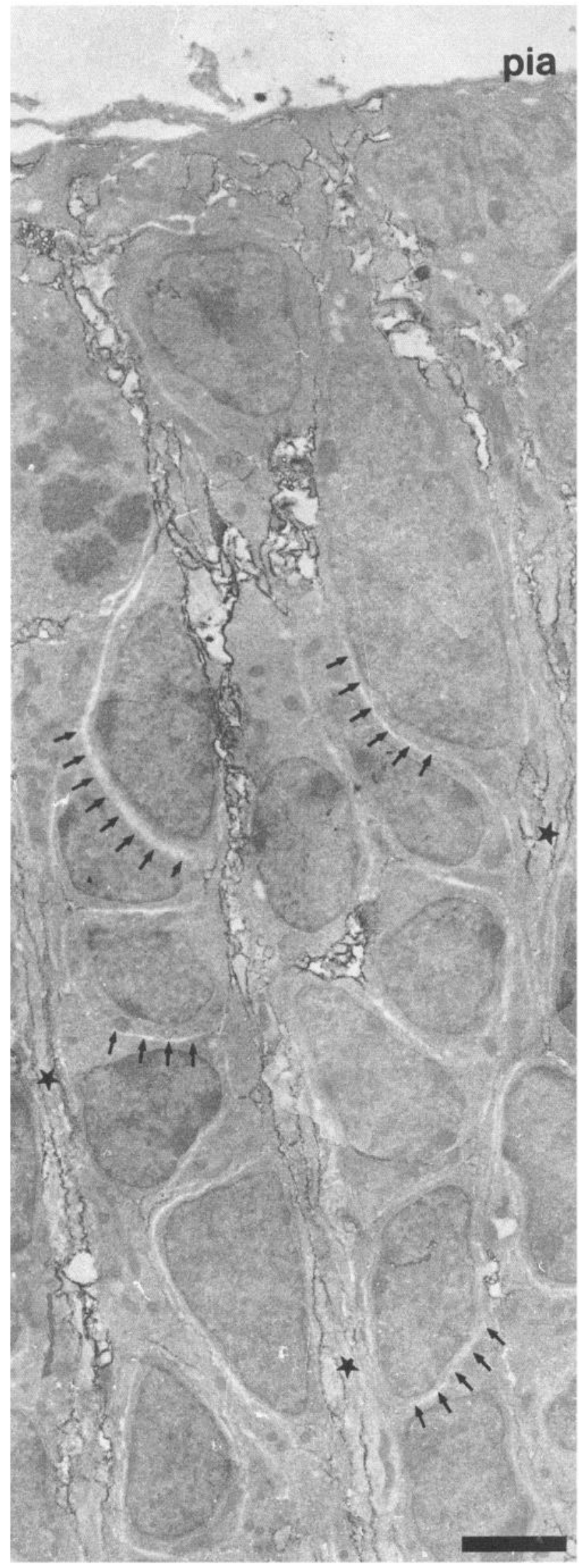

immunofluorescence microscopy (Fig. 1a-c) when compared to later ages (Fig. $1 d$ and not shown). From the fourth postnatal week onward, the intensity of tenascin immunoreactivity decreased significantly. In the adult, tenascin immunoreactivity was weak and mainly restricted to the molecular layer (Fig. 1d).

In the external granular layer of neonatal (Fig. 1a) and 7-dold animals (Fig. 1b), radially oriented tenascin-immunoreactive structures were visible, corresponding to processes of Golgi epithelial cells, the Bergmann fibers (see also Fig. 2). The densely packed cell bodies of the external granular layer, in contrast, were immunonegative. The developing molecular layer showed a homogeneously distributed immunoreactivity (Fig. 1a,b), not only during the first 3 weeks (Fig. $1 a-c$ ), but also at later ages, although with a significantly reduced intensity (Fig. $1 d$ ). The internal granular layer and prospective white matter showed intense immunolabeling during the first 3 postnatal weeks (Fig. $1 a-c)$, but only weak immunoreactivity in the adult (Fig. 1d). The staining pattern obtained with the two monoclonal antibodies $\mathrm{J} 1 / \operatorname{tn} 1$ (Fig. $1 f$ ) and $\mathrm{J} 1 / \mathrm{tn} 2$ (Fig. $1 e$ ) in 7-d-old animals was similar to that seen with polyclonal antibodies at the same developmental stage (Fig. 1b).

For comparison, the cerebellar cortex of a 7-d-old mouse was stained with polyclonal antibodies to the neural recognition molecule L1 (Fig. 1g). L1 was detectable in a different staining pattern being localized in the internal part of the external granular layer, the molecular layer, and throughout the internal granular layer. It is noteworthy that staining intensity and staining pattern of $\mathrm{L} 1$ and tenascin in the developing molecular layer were comparable (compare Fig. $1 b, e, f$ with $g$ ). As a negative control, incubation of cryostat sections with primary antibodies was omitted and neither FITC-conjugated swine anti-rabbit (Fig. $1 h$ ) nor FITC-conjugated goat anti-rat IgG (Fig. $1 i$ ) antibodies gave any background labeling.

\section{Immunoelectron microscopic localization of tenascin in the developing mouse cerebellar cortex}

By indirect immunoelectron microscopy, tenascin was detectable in the external granular layer of a 7-d-old mouse cerebellar cortex at the surface of radially oriented processes of Golgi epithelial cells (Fig. 2). The conical end feet of these processes at the pial surface were also immunoreactive. Cell bodies located in the external granular layer were immunonegative at contact sites to each other (Fig. 2).

In the molecular layer of a 9-d-old mouse, parallel fibers were strongly stained by tenascin antibodies (Fig. 3). Parallel fibers were not only immunoreactive at contact sites with each other, but also at contact sites with Purkinje cell dendrites or Purkinje, basket, or stellate cell bodies (Fig. 3).

Tenascin immunoreactivity was hardly detectable at contact sites between migrating granule cells and radially oriented processes of Golgi epithelial cells (Fig. 4) in 7- or 9-d-old mice. To assure that proper penetration of antibodies had occurred, only

Figure 2. Immunoelectron microscopic localization of tenascin in the external granular layer of the cerebellar cortex of a 7-d-old mouse. The distribution of tenascin was analyzed by indirect immunoelectron microscopy in parasagittal sections of the cerebellar cortex using polyclonal antibodies. The densely packed cell bodies are devoid of tenascin immunoreactivity at contact sites with each other (arrows). Radially oriented processes of Golgi epithelial cells (asterisks) extending to the pial surface (pia) are labeled by tenascin antibodies. Scale bar, $2 \mu \mathrm{m}$. 


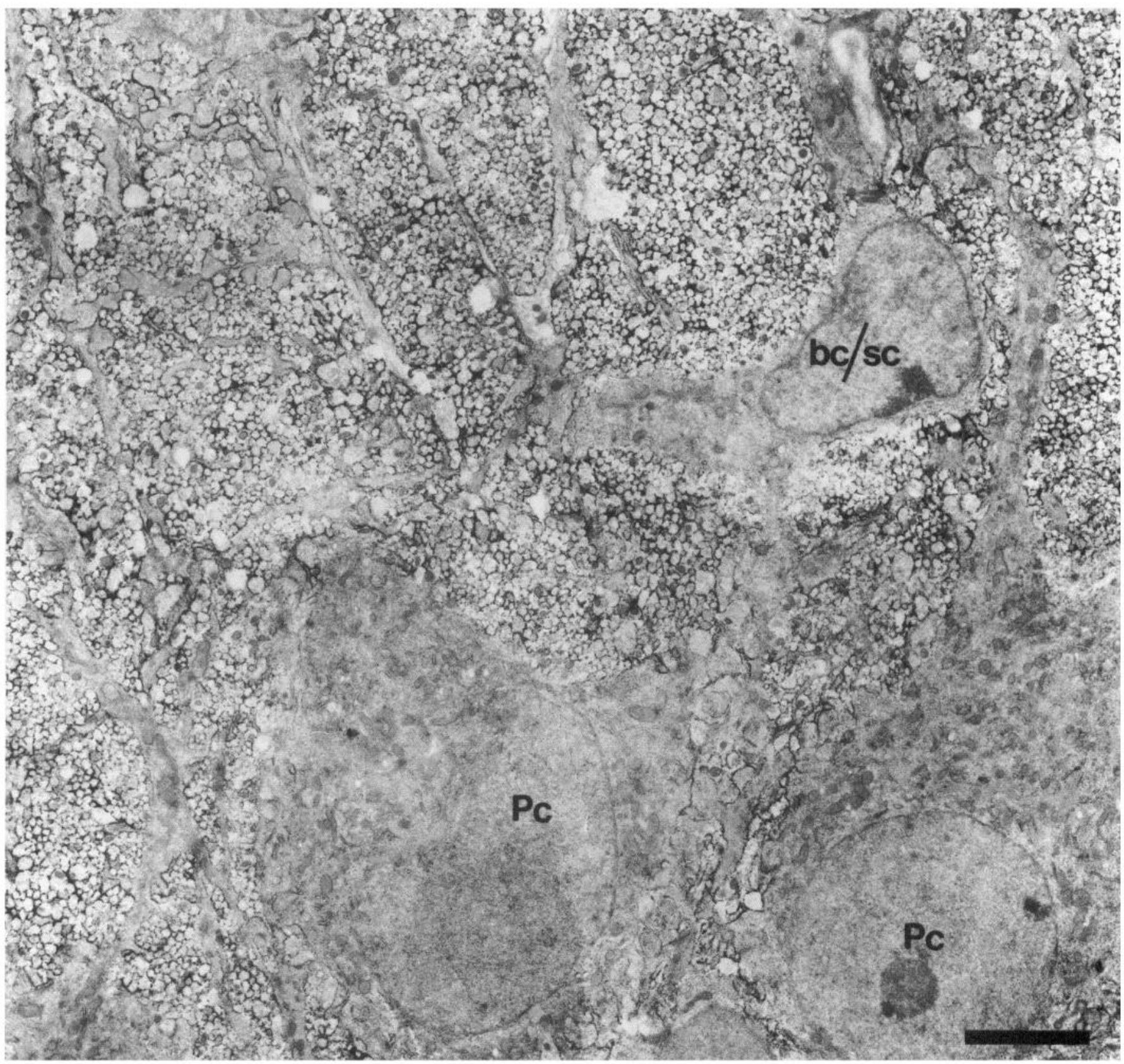

Figure 3. Immunoelectron microscopic localization of tenascin in the molecular layer of the cerebellar cortex of a 9-d-old mouse. The distribution of tenascin was analyzed by indirect immunoelectron microscopy in parasagittal sections of the cerebellar cortex using polyclonal antibodies. Cell surfaces of parallel fibers are strongly labeled by tenascin antibodies. Immunoreactivity is detectable not only at contact sites between parallel fibers, but also at contact sites between parallel fibers and Purkinje cell bodies $(P c)$ and dendrites and parallel fibers and cell bodies of basket or stellate cells $(b c / s c)$. Scale bar, $5 \mu \mathrm{m}$.

those contact sites that were surrounded by immunolabeled structures were analyzed for tenascin immunoreactivity.

In the internal granular layer of a 9-d-old mouse cerebellar cortex, granule cell bodies were tenascin immunonegative at contact sites with each other, whereas cell processes in the immediate neighborhood were strongly immunolabeled by tenascin antibodies (Fig. 5).

\section{Localization of tenascin mRNA in the developing and adult mouse cerebellar cortex}

By in situ hybridization, cell bodies of Golgi epithelial cells, identified by their size and location near the Purkinje cell layer, were labeled in the cerebellar cortex of 7-d-old animals with both digoxigenin-labeled (Fig. 6a,c) and ${ }^{35}$ S-labeled (Fig. 6d) cRNA probes. Cell bodies of Purkinje cells were not labeled (Fig. 6c). Cells containing tenascin mRNA were scattered throughout the internal granular layer and prospective white matter (Fig. $6 a, d$ ). These cells were judged to be astrocytes from the size of their cell bodies and their overall distribution and density. No tenascin mRNA-containing cells were detectable in the external granular and molecular layer at 0,2 (not shown), or $7 \mathrm{~d}$, either with digoxigenin-labeled (Fig. $6 a, c$ ) or with ${ }^{35} \mathrm{~S}-$ labeled (Fig. $6 d$ ) cRNA probes. In the adult, only Golgi epithelial cells located in the region of the Purkinje cell layer expressed 


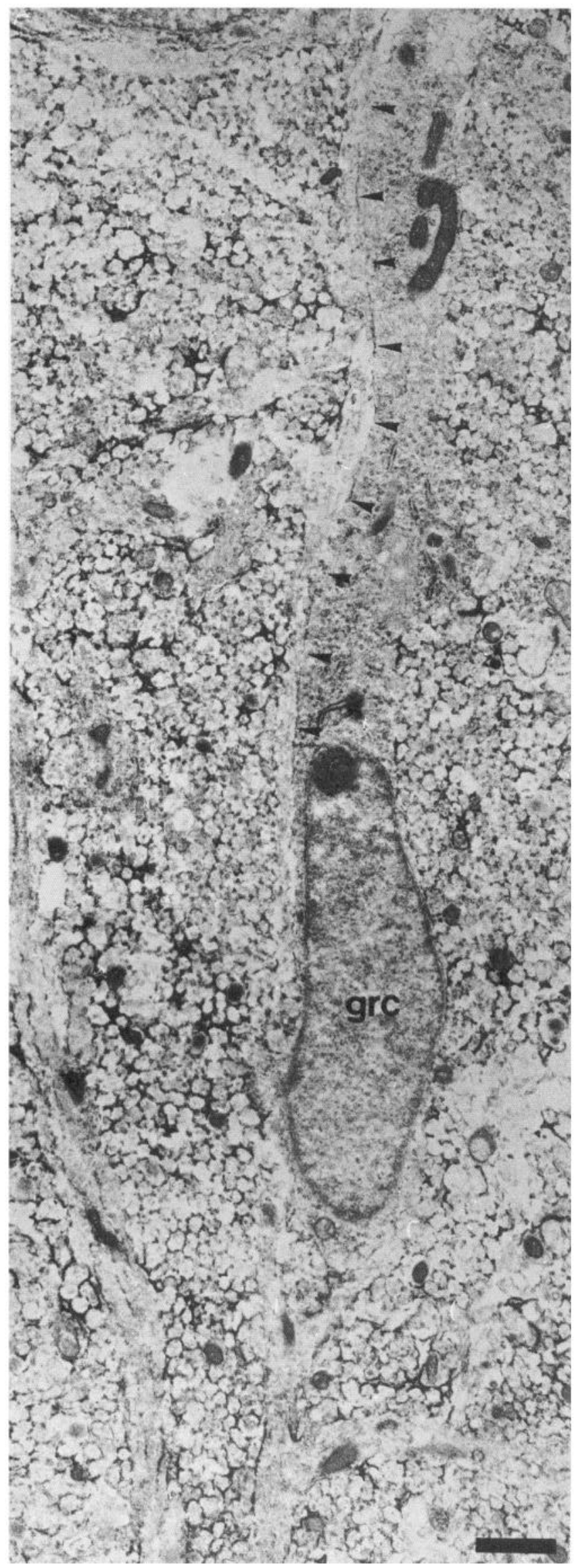

detectable levels of tenascin mRNA (Fig. 7a). All other cortical layers were devoid of labeled cells (not shown). No hybridization signal was seen in control sections, which were hybridized with either digoxigenin-labeled (Figs. $6 b, 7 b$ ) or ${ }^{35}$ S-labeled (Fig. 6e) sense probes.

\section{Northern blot analysis of tenascin $m R N A$ expression during cerebellar development}

In order to gain information about the overall expression level of tenascin-specific mRNAs during development, and the contribution of different mRNA isoforms to the signal in in situ hybridization, Northern blots of cerebellar RNA isolated from different developmental stages were prepared. Hybridization with a tenascin-specific cRNA probe revealed at least two bands around $6 \mathrm{~kb}$ and $8 \mathrm{~kb}$, in agreement with the previously described mRNA species found for mouse tenascin (Weller et al., 1991). Overall expression of tenascin mRNA generally decreased in the course of cerebellar development, with the highest expression at postnatal day 0 and only very weak expression at adult stages (Fig. 8). However, the decrease in mRNA level was found to follow different time courses for the two mRNA isoforms. Expression of the $8 \mathrm{~kb}$ mRNA was most prominent at postnatal day 0 , with a decrease at postnatal day 7 . No signal was detectable for the $8 \mathrm{~kb}$ isoform at postnatal day 14 or at adult stages. Expression of the $6 \mathrm{~kb}$ mRNA species was already clearly detectable at postnatal days 0 and 7 but, in contrast to the $8 \mathrm{~kb}$ mRNA species, reached its highest level at postnatal day 14. In adults, hybridization signal for the $6 \mathrm{~kb}$ mRNA went down to a very low level. This is consistent with the signal intensity found in in situ hybridization in adult cerebellar tissue, which was, although not precisely quantified, found to be substantially reduced compared to sections from postnatal day 7 . From these data, it can be concluded that the signal observed by in situ hybridization in adult cerebellar cortex is mainly, if not entirely, due to expression of the $6 \mathrm{~kb}$ mRNA species.

\section{Quantitative immunoblot analysis of tenascin isoform expression in developing and adult mouse cerebellum}

To investigate which tenascin isoforms are expressed at the protein level during cerebellar development, immunoblot analysis of crude membrane fractions from cerebella of mice from postnatal day 0 to adult ( $>60$ d) was carried out. Generally, the high molecular weight components decreased at earlier developmental stages than the low molecular weight ones (Fig. 9). On days 0 and 7 , prominent components were visible at 200 $\mathrm{kDa}$ and $240 \mathrm{kDa}$ (Fig. 9). Shorter exposure times revealed that the $240 \mathrm{kDa}$ component at 0 and $7 \mathrm{~d}$ consisted of a doublet of closely comigrating bands, which could be distinguished at longer exposure times at postnatal day 14 , when the relative concentration of these components was reduced (Fig. 9 and not shown). The low molecular weight component of tenascin consisted of a prominent band at $200 \mathrm{kDa}$ on days 0 and 7 . At

\footnotetext{
Figure 4. Immunoelectron microscopic localization of tenascin in the molecular layer of the cerebellar cortex of a 9-d-old mouse. The distribution of tenascin was analyzed by indirect immunoelectron microscopy in parasagittal sections of the cerebellar cortex using polyclonal antibodies. No significant tenascin immunoreactivity is detectable at the contact site between a migrating granule cell ( $g r c)$ and the process of a Golgi epithelial cell (arrowheads). Note that the parallel fibers in the immediate neighborhood of this migrating cell are labeled by tenascin antibodies. Scale bar, $1 \mu \mathrm{m}$.
} 


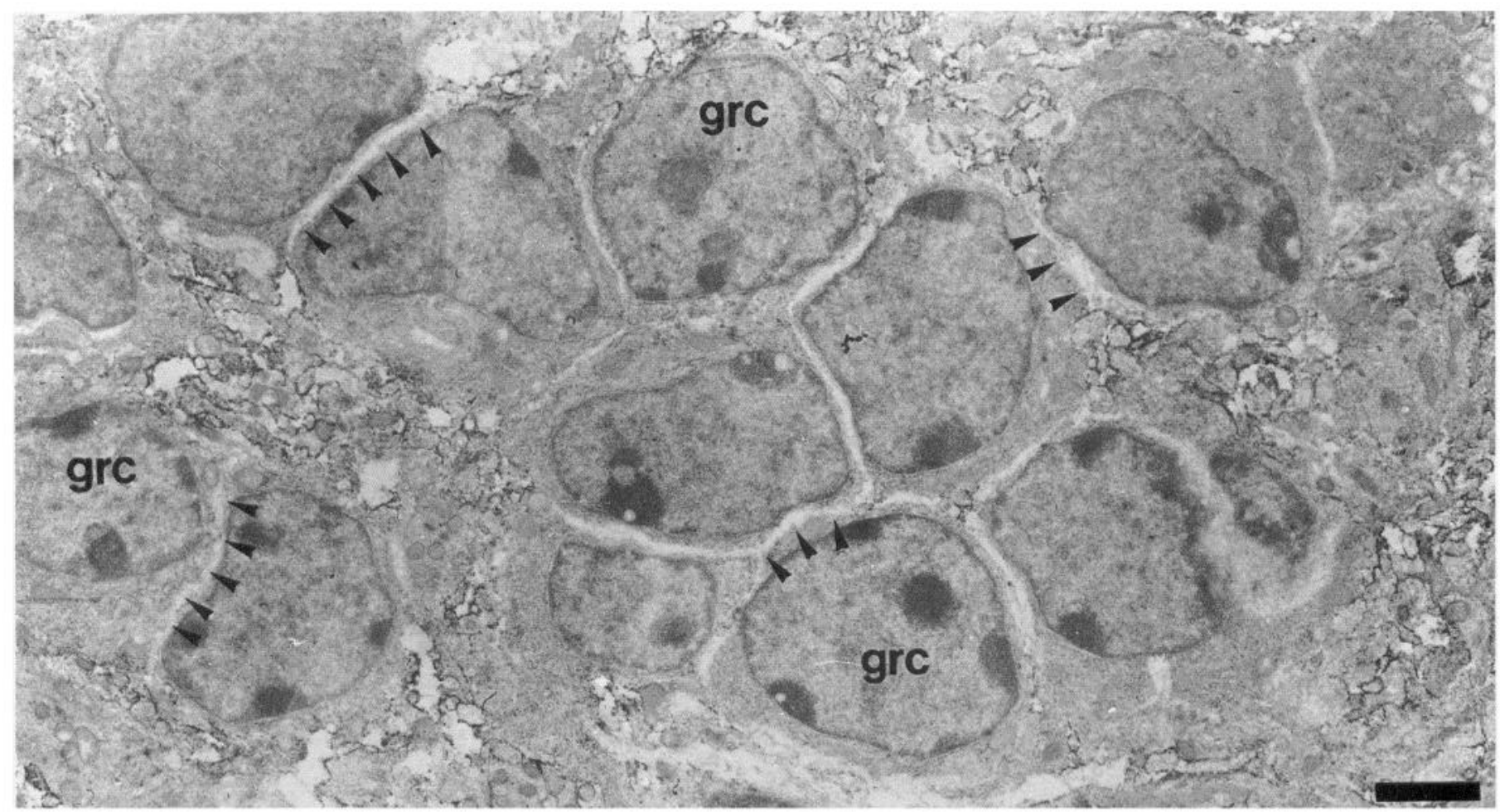

Figure 5. Immunoelectron microscopic localization of tenascin in the internal granular layer of the cerebellar cortex of a 9-d-old mouse. The distribution of tenascin was analyzed by indirect immunoelectron microscopy in parasagittal sections of the cerebellar cortex using polyclonal antibodies. Cell bodies of granule cells $(\mathrm{grc})$ are tenascin immunonegative at contact sites with each other (arrowheads). In contrast, tenascin immunoreactivity is detectable at the surface of cellular processes located in the immediate neighborhood. Scale bar, $2 \mu \mathrm{m}$.

postnatal day 14 , an additional band of about $190 \mathrm{kDa}$ appeared that persisted, although at low levels, until adult stages, displaying a slower decrease than the accompanying $200 \mathrm{kDa}$ form. The ratio of detectable immunoreactivity on the $225 / 240 \mathrm{kDa}$ as compared to the $190 / 200 \mathrm{kDa}$ band doublet shifted from $3: 1$ at postnatal day 0 to about 1:5 at postnatal day 21 (Fig. 10). The quantitative determination of tenascin in developing cerebellar tissues was performed by comparison with a calibration curve using the purified molecule. At postnatal day 0 , the time point of highest expression, the extracellular matrix constituent amounted to $0.1 \%$ of the total membrane proteins ( $250 \mathrm{ng}$ in $250 \mu$ g protein).

\section{Discussion}

\section{Expression of tenascin is developmentally regulated}

We have shown that tenascin and tenascin mRNA are amply detectable in tissue sections from cerebella of early postnatal animals and that expression is strongly reduced in cerebella of adult animals. The downregulation of tenascin polypeptides and mRNAs in mice was observed up to the third or fourth postnatal week, roughly coinciding with the end of cerebellar histogenesis (Fujita et al., 1967). High expression of immunocytochemically detectable tenascin during early developmental stages and subsequent downregulation at later developmental stages have been described also in other regions of the CNS, as for instance in the somatosensory cortex (Crossin et al., 1989; Steindler et al., 1989a) and optic nerve (Bartsch, Bartsch, and Schachner, unpublished observations) of the mouse. Also, immunochemical analysis revealed a downregulation of tenascin expression in total brain tissue of mouse and chicken (Kruse et al., 1985;
Hoffman et al., 1988; Crossin et al., 1989), suggesting a critical role of this molecule for the formation of several brain regions.

The tenascin components with apparent molecular weights of 190 and $200 \mathrm{kDa}$ showed a slower developmental downregulation than the 225 and $240 \mathrm{kDa}$ components, reminiscent of findings in the mouse cerebral cortex (Crossin et al., 1989). Recent data on the derived amino acid sequences of mouse and chicken tenascin glycoproteins have shown that distinct mRNAs for individual isoforms of the molecule are generated by differential splicing (Jones et al., 1989; Spring et al., 1989; Weller et al., 1991). A change in the expression of the different tenascin mRNA species was also observed by Northern blot analysis. Consistent with the results obtained by immunoblots, an overall downregulation of tenascin mRNA expression occurs during development. Although the precise relationship between the protein bands observed in immunoblots and the mRNA species is at present not known, it is striking that the developmental regulation of the $225 / 240 \mathrm{kDa}$ band doublet corresponds to the expression of the $8 \mathrm{~kb}$ mRNA species whereas the $190 / 200 \mathrm{kDa}$ band doublet corresponds to the expression of the $6 \mathrm{~kb}$ mRNA species. Either the two doublets are generated by posttranslational modifications from the two mRNA species observed in Northern blots, or other, as yet unidentified mRNA species exist that could not be resolved by Northern blotting. Surprisingly, in the cerebellar cortex of chicken, downregulation of the lowmolecular-weight isoforms is more prominent than of the highmolecular-weight isoforms (Prieto et al., 1990), indicative of different functions of distinct tenascin isoforms in different species.

A shift in the expression of tenascin components has also 

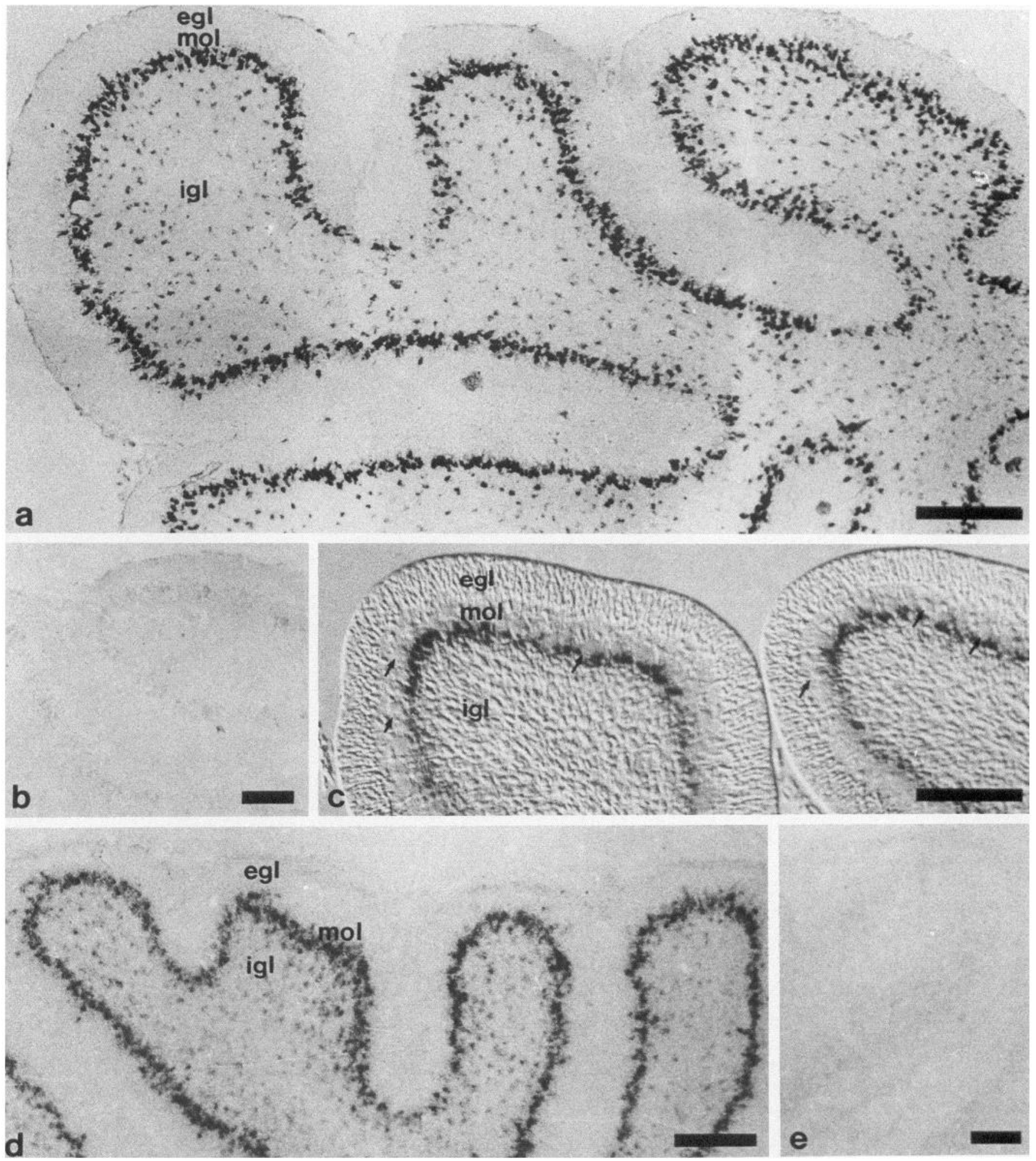

Figure 6. Localization of tenascin mRNA in the cerebellar cortex of a 7-d-old mouse by in situ hybridization. Many small cell bodies are labeled close to the Purkinje cell layer with both digoxigenin-labeled $(a, c)$ and ${ }^{35}$ S-labeled $(d)$ cRNA probes. Using differential interference contrast

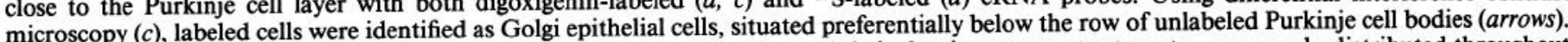
In addition, labeled cells, which according to the size of their cell bodies and their density represent astrocytes, are evenly distributed throughout the internal granular layer $(i g l)$ and prospective white matter $(a, d)$. No labeled cells were detectable in the external granular layer $(e g l)$ or developing the internal granular layer $(\mathrm{igl})$ and prospective white matter $(a, d)$. No labeled cells were Scale bars: $a$ and $d, 200 \mu \mathrm{m} ; b, c$, and $e, 100 \mu \mathrm{m}$. 

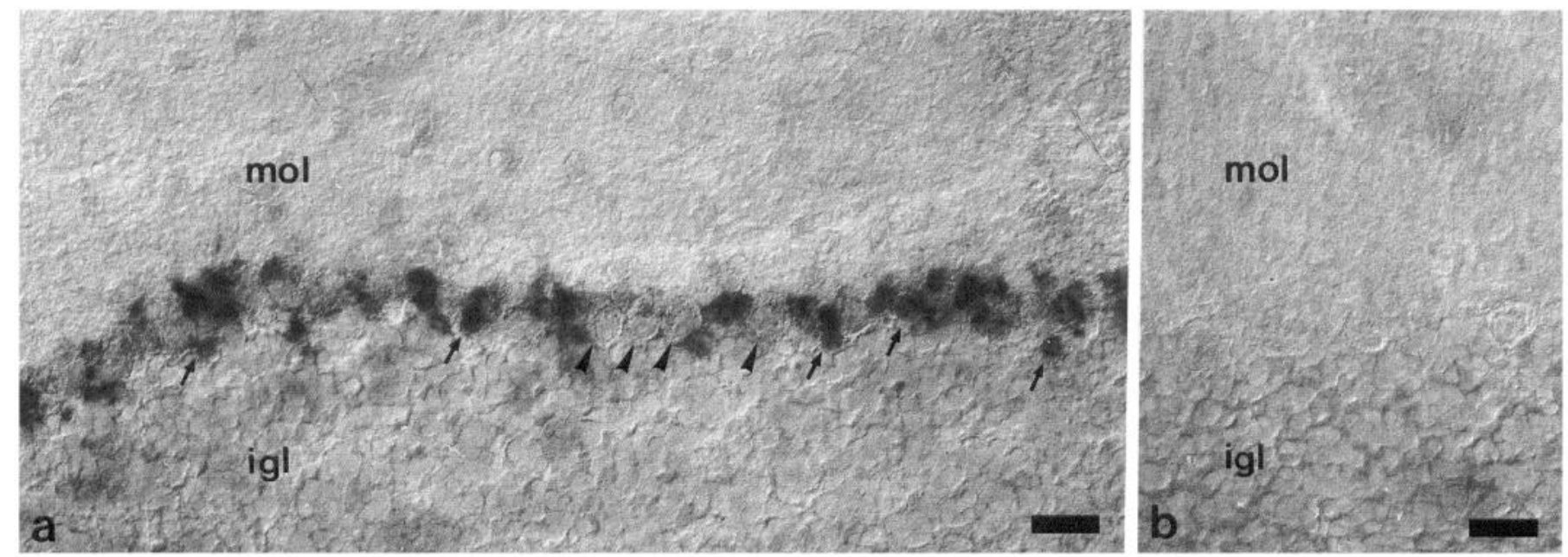

Figure 7. Localization of tenascin mRNA in the cerebellar cortex of an adult mouse by in situ hybridization. In the adult mouse cerebellar cortex, tenascin mRNA is only detectable close to the Purkinje cell layer in cell bodies of Golgi epithelial cells (arrows in $a$ ). Cell bodies of Purkinje cells (arrowheads in $a$ ), in contrast, are unlabeled. The molecular layer $(\mathrm{mol})$ and internal granular layer (igl) do not contain labeled cells. Control sections, hybridized with digoxigenin-labeled sense probe, were unlabeled $(b)$. Scale bars, $25 \mu \mathrm{m}$.

been reported for the developing intestine, with the lower-molecular-weight components preceding those of $260 \mathrm{kDa}$ (Aufderheide and Ekblom, 1988). On the other hand, in regenerating tissues, such as the mouse sciatic nerve and the amphibian tail bud, a transient but concomitant increase in expression of the major tenascin components has been observed (Arsanto et al., 1990; Martini et al., 1990). The functional differences between the isoforms are not known, but it is plausible that they play distinct roles during development and regeneration.

\section{Glial cells are the source of neuron-associated tenascin in the cerebellar cortex}

An important finding of this study was the unequivocal demonstration of an association of tenascin with the cell surface of cerebellar neurons. Interestingly, tenascin is differentially distributed on neuronal surfaces. Granule cell bodies in the internal granular layer are immunonegative at contact sites with each other, while granule cell axons in the molecular layer are strongly immunoreactive. Similarly, unmyelinated retinal ganglion cell axons have been described to be tenascin immunoreactive in the developing mouse optic nerve (Bartsch, Bartsch, and Schachner, unpublished observations). In situ hybridization experiments indeed show that Golgi epithelial cells and astrocytes of the internal granular layer and prospective white matter synthesize tenascin. None of the different nerve cell types in the cerebellar cortex, however, showed detectable levels of tenascin mRNA, in agreement with other recently published studies (Prieto et al., 1990; Tsukamoto et al., 1991). Our study suggests that the nerve cell-associated tenascin could be of glial origin and that the putative neuronal receptor(s) for tenascin is differentially distributed on the neuronal cell surface. Thus, the functional properties of nerve cell surfaces may become modified by secreted, morphogenetically relevant glia-derived molecules.

\section{Tenascin expression in the adult mouse cerebellar cortex reveals a heterogeneity in astrocytes}

The weak tenascin immunoreactivity in the cerebellar cortex of adult mice indicates that the molecule is still expressed after the termination of cerebellar histogenesis. Also, immunoblot anal- ysis revealed the presence of the lower-molecular-weight components of tenascin in the adult cerebellum. This expression at the protein level was paralleled by the detectability of tenascin mRNA by Northern blot analysis and in situ hybridization. Interestingly, only Golgi epithelial cells, and not astrocytes of the molecular layer, internal granular layer, or white matter, expressed detectable levels of tenascin mRNA, indicating a functional heterogeneity in cerebellar astrocytes. A similar heterogeneity of astrocytes has been observed in the optic nerve of adult mice in that only astrocytes located in the unmyelinated proximal part of the optic nerve contain detectable levels of tenascin mRNA, but not astrocytes of the myelinated optic nerve proper (U. Bartsch, A. Faissner, J. Trotter, U. Dörries, S. Bartsch, and M. Schachner, unpublished observations). The signals leading to the continued expression of tenascin by only a small population of astrocytes in the adult CNS will have to be determined.

\section{Possible functional roles of tenascin in the developing and adult cerebellar cortex}

In addition to neuron-glia adhesion (Grumet et al., 1985; Kruse et al., 1985), tenascin has been shown to be functionally involved in neurite outgrowth (Chiquet, 1989; Wehrle and Chiquet, 1990; Lochter et al., 1991) and cell migration (Chuong et al., 1987; Tan et al., 1987; Bronner-Fraser, 1988; Halfter et al., 1989). Migration of cerebellar granule cells from the external to the internal granular layer is affected by antibodies to tenascin in cerebellar explant culture systems (Chuong et al., 1987; Husmann, Faissner, and Schachner, unpublished observations), possibly by reducing the migration rate of granule cells or by blocking the transition of cells from the molecular layer to the internal granular layer (Chuong et al., 1987). However, direct effects on cerebellar granule cell migration have to modify interactions between migrating granule cells and Golgi epithelial cells, since the processes of these glial cells are the substrate for migrating granule cells (Rakic, 1971; Hatten et al., 1984; Edmondson and Hatten, 1987). Surprisingly, tenascin was hardly detectable at the interface between migrating granule cells and processes of Golgi epithelial cells at the ultrastructural level. 


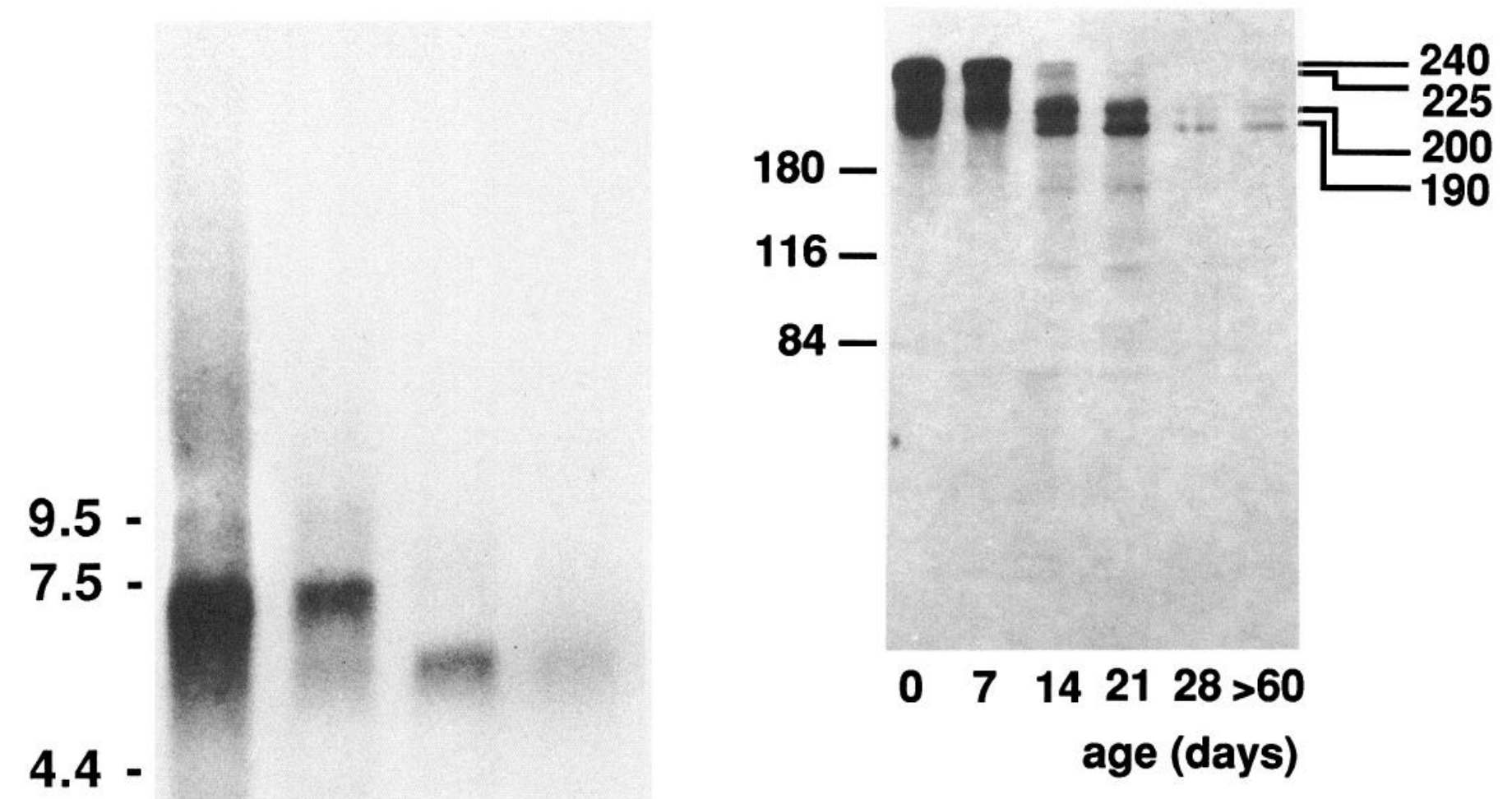

Figure 9. Immunoblot analysis of tenascin glycoproteins in the cerebellum of mice at different ages. Crude membrane fractions $(250 \mu \mathrm{g} /$ lane) of cerebella from different ages were resolved by 7\% SDS-PAGE and transferred to nitrocellulose filters which were developed with ${ }^{125} \mathrm{I}-$ labeled protein A. An autoradiograph of a representative blot is shown. The estimated molecular weights of tenascin immunoreactive bands of $190 \mathrm{kDa}, 200 \mathrm{kDa}, 225 \mathrm{kDa}$, and $240 \mathrm{kDa}$ are indicated on the right side of the figure. The individual components of the $225 / 240 \mathrm{kDa}$ doublet at postnatal days 0 and 7 are visible upon shorter exposure times. The molecular weight standards fructose-6-phosphate kinase $(84 \mathrm{kDa})$, $\beta$-galactosidase $(116 \mathrm{kDa})$, and $\alpha$-macroglobulin $(180 \mathrm{kDa})$ are indicated on the left side of the figure.

\section{$\begin{array}{llll}0 & 7 & 14 & >60\end{array}$ age (days)}

Figure 8. Northern blot analysis of mouse cerebella of different ages. $\mathrm{PolyA}^{+}$RNA from neonatal, 7-d-old, 14-d-old, and adult mouse cerebella ( $5 \mu \mathrm{g} /$ lane) was separated on a $0.8 \%$ formaldehyde/agarose gel and blotted onto a Hybond $\mathrm{N}$ membrane (Amersham). Hybridization was performed with a ${ }^{32} \mathrm{P}$-labeled $2 \mathrm{~kb}$ antisense cRNA transcript from plasmid pJT1. After hybridization and washing, the $\mathrm{x}$-ray film was exposed for $36 \mathrm{hr}$ for autoradiography. The size of RNA marker bands is indicated in kilobases.

Although we cannot completely rule out that we were unable to penetrate this cell contact with tenascin antibodies, we consider this explanation unlikely, since the presence of N-CAM (Persohn and Schachner, 1987) or its highly sialylated form (Hekmat et al., 1990) has been demonstrated at this particular cell-cell contact using comparable immunocytochemical protocols. Migration of granule cells is also affected by $\mathrm{Ll}$ or $\mathrm{Ng}$ CAM antibodies (Lindner et al., 1983; Chuong et al., 1987). The effect of $\mathrm{L} 1$ antibodies is hypothesized to be only indirect, since L1 is supposed to mediate neuron-neuron but not neuronglia interactions (Keilhauer et al., 1985) and since L1 is not detectable at the interface between migrating granule cells and processes of Golgi epithelial cells (Persohn and Schachner, 1987). Instead, it has been hypothesized that L1 antibodies modify granule cell migration indirectly, possibly by perturbing the sorting out of postmitotic nerve cells or by interfering with the extension of granule cell axons (Keilhauer et al., 1985). However, a similar indirect effect of tenascin antibodies on granule cell migration seems unlikely, since granule cell migration is only affected during its late phase, when granule cells have already entered the molecular layer (Chuong et al., 1987) and thus are associated with processes of Golgi epithelial cells. Possibly, the low and sometimes hardly detectable tenascin immunoreactivity at contact sites between migrating granule cells and processes of Golgi epithelial cells is of functional significance, or tenascin may be more strongly expressed at contact sites between Golgi epithelial cell processes and functional relevant cellular domains of migrating granule cells, like their leading tips.

The entire thickness of the molecular layer is strongly tenascin immunoreactive in the young postnatal cerebellar cortex. The youngest parallel fibers are located in the upper zone of the molecular layer, since later formed fibers become stacked on 


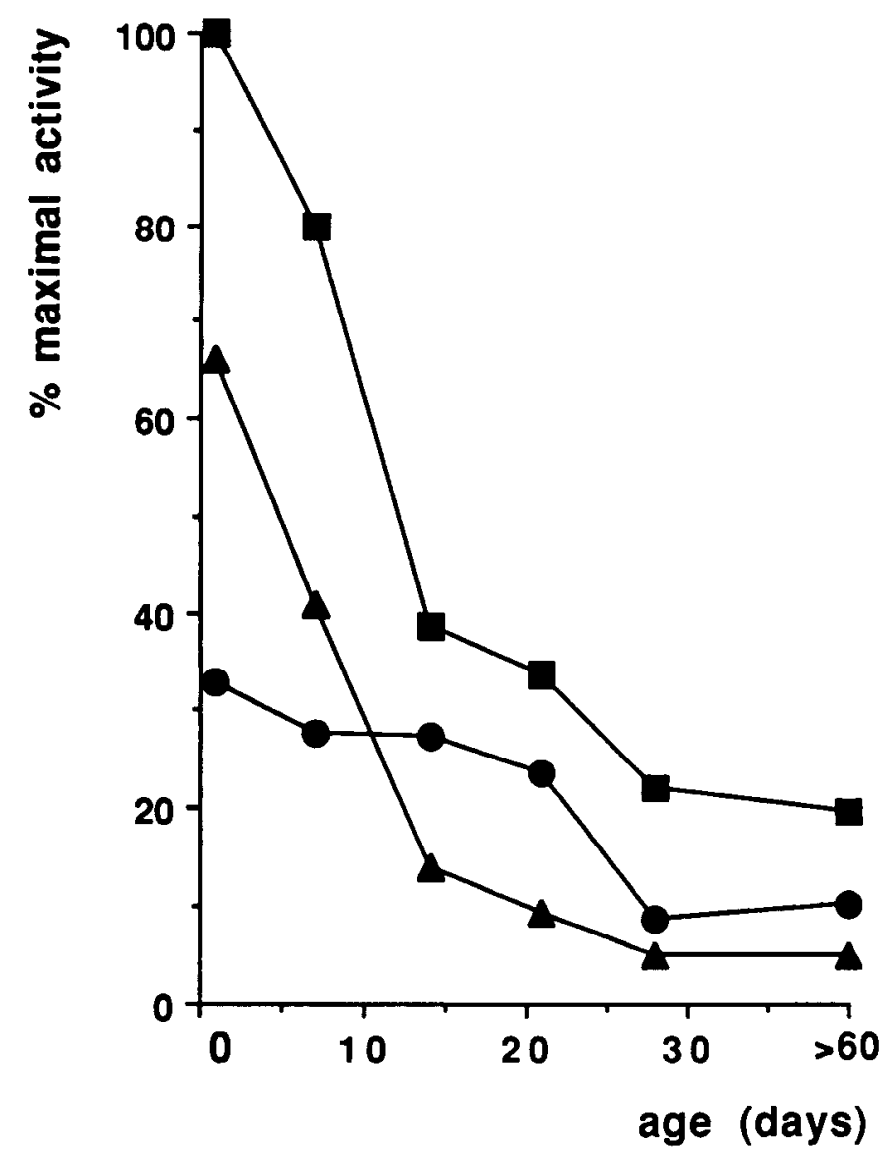

Figure 10. Quantitative determination of tenascin expression in the cerebellum of mice at different ages. Areas of the immunoblot filter (Fig. 9) carrying the $190 / 200 \mathrm{kDa}$ and $225 / 240 \mathrm{kDa}$ tenascin band doublets were cut out and the respective activities were quantified. Measurements were pooled for each time point (squares) and the highest value, which was obtained at postnatal day 0 , was set $100 \%$. Activities determined for the $190 / 200 \mathrm{kDa}$ area (circles), and 225/240 $\mathrm{kDa}$ region (triangles) and the sums of both activities (squares) were expressed as percentage fractions of the summed activities recorded at postnatal day 0 (highest level of expression, $100 \%$ ). Background was estimated by measuring parts of the immunoblot filter that did not display tenascin immunoreactivity and was $5 \pm 2 \%(n=3)$ of the reference value at postnatal day 0 .

earlier formed parallel fibers (Altman, 1972). Thus, growth of parallel fibers occurs through a tenascin-positive environment, possibly by using other tenascin-immunoreactive parallel fibers as a substrate. It is interesting in this context that high levels of tenascin can be found during the period of sciatic nerve regeneration in the mouse (Martini et al., 1990) and chicken (Daniloff et al., 1989) with a subsequent downregulation after axonal regrowth. Similarly, tenascin levels increase after denervation of the neuromuscular junction and decrease again after reinnervation of the muscle (Sanes et al., 1986; Gatchalian et al., 1989). These observations, together with the increased immunoreactivity associated with growing fiber tracts, like the stratum opticum of the developing chick optic tectum (Crossin et al., 1986; S. Bartsch and M. Schachner, unpublished observations) or the developing mouse optic nerve (Bartsch, Bartsch, and Schachner, unpublished observations) are indicative of a neurite outgrowth-promoting activity of tenascin. Such functional properties of this molecule have recently been demonstrated in in vitro experiments (Chiquet, 1989; Wehrle and Chiquet, 1990; Lochter et al., 1991).

The high and homogeneously distributed tenascin immunorcactivity in the developing molecular layer and the continued tenascin positivity of this layer in adult animals as a result of the continued mRNA expression by Golgi epithelial cells might have a functional significance for the distribution of oligodendrocytes. Recently, we have shown in two-choice experiments that a tenascin substrate has nonpermissive properties for oligodendrocyte attachment (Bartsch, Faissner, Trotter, Dörries, Bartsch, and Schachner, unpublished observations). Oligodendrocytes and their progenitor cells are thought to derive from the subependymal layer of the fourth ventricle and to migrate into the cerebellar cortex via the superior medullary velum and the cerebellar peduncles (Curtis et al., 1988; Reynolds and Wilkin, 1988). Since the molecular layer of the mouse cerebellar cortex contains no oligodendrocytes or myelinated fibers, it is tempting to speculate that the increased tenascin immunoreactivity prevents these cells from entering the molecular layer.

In summary, our observations demonstrate that tenascin in the cerebellar cortex is a glia-derived molecule that is also detectable on nerve cell surfaces. Expression of tenascin decreases significantly with increasing age, being most prominently expressed during the period of cerebellar histogenesis. Tenascin isoforms are differentially regulated during development, suggesting that the different tenascin glycoproteins differ in their functional significance. The spatiotemporal expression pattern of the molecule indicates that it may be involved in such different morphogenetic events as neurite growth and oligodendrocyte distribution.

\section{References}

Altman J (1972) Postnatal development of the cerebellar cortex in the rat. I. The external germinal layer and the transitional molecular layer. J Comp Neurol 145:353-398.

Altman J (1982) Morphological development of the rat cerebellum and some of its mechanisms. In: The cerebellum - new vistas (Palay SL, Chan-Palay V, eds), pp 8-49. Berlin: Springer.

Antonicek H, Persohn E, Schachner M (1987) Biochemical and functional characterization of a novel neuron-glia adhesion molecule that is involved in neuronal migration. J Cell Biol 104:1587-1595.

Arsanto J-P, Diano M, Thouveny Y, Thiery J-P, Levi G (1990) Patterns of tenascin expression during tail regeneration of the amphibian urodele Pleurodeles Waltl. Development 109:177-188.

Aufderheide E, Ekblom P (1988) Tenascin during gut development: appearance in the mesenchyme, shift in molecular forms, and dependence on epithelial-mesenchymal interactions. J Cell Biol 107: 2341-2349.

Bartsch U, Kirchhoff F, Schachner M (1989) Immunohistological localization of the adhesion molecules L1, N-CAM, and MAG in the developing and adult optic nerve of mice. J Comp Neurol 284:451462.

Bartsch U, Kirchhoff F, Schachner M (1990) Highly sialylated N-CAM is expressed in adult mouse optic nerve and retina. J Neurocytol 19: $550-565$.

Bixby JL, Lilien J, Reichardt LF (1988) Identification of the major proteins that promote neuronal process outgrowth on Schwann cells in vitro. J Cell Biol 107:353-362.

Bronner-Fraser M (1988) Distribution and function of tenascin during cranial neural crest development in the chick. J Neurosci Res 21: 135-147.

Chang S, Rathjen FG, Raper JA (1987) Extension of neurites on axons is impaired by antibodies against specific neural cell surface glycoproteins. J Cell Biol 104:355-362.

Chiquet M (1989) Tenascin/J1/cytotactin: the potential function of hexabrachion proteins in neural development. Dev Neurosci 11:266275.

Chiquet-Ehrismann R, Mackie EJ, Pearson CA, Sakakura T (1986) 
Tenascin: an extracellular matrix protein involved in tissue interactions during fetal development and oncogenesis. Cell 47:131-139.

Chomczynski P, Sacchi N (1987) Single-step method of RNA isolation by acidic guanidinium thiocyanate-phenol-chloroform extraction. Anal Biochem 162:156-159.

Chuong C-M, Crossin KL, Edelman GM (1987) Sequential expression and differential function of multiple adhesion molecules during the formation of cerebellar cortical layers. J Cell Biol 104:331-342.

Cowan WM (1982) A synoptic view of the development of the vertebrate central nervous system. Life Sci Res Rep 24:7-24.

Crossin KL, Hoffman S, Grumet M, Thiery J-P, Edelman GM (1986) Site-restricted expression of cytotactin during development of the chicken embryo. J Cell Biol 102:1917-1930.

Crossin KL, Hoffman S, Tan S-S, Edelman GM (1989) Cytotactin and its proteoglycan ligand mark structural and functional boundaries in somatosensory cortex of the early postnatal mouse. Dev Biol 136: 381-392.

Curtis R, Cohen J, Fok-Seang J, Hanley MR, Gregson NA, Reynolds $R$, Wilkin GP (1988) Development of macroglial cells in rat cerebellum. I. Use of antibodies to follow early in vivo development and migration of oligodendrocytes. J Neurocytol 17:43-54.

Daniloff JK, Crossin KL, Pincon-Raymond M, Murawsky M, Rieger F, Edelman GM (1989) Expression of cytotactin in the normal and regenerating neuromuscular system. J Cell Biol 108:625-635.

Drazba J, Lemmon V (1990) The role of cell adhesion molecules in neurite outgrowth on Müller cells. Dev Biol 138:82-93.

Edelman GM (1986) Cell adhesion molecules in the regulation of animal form and tissue pattern. Annu Rev Cell Biol 2:81-116.

Edmondson JC, Hatten ME (1987) Glial-guided granule neuron migration in vitro: a high-resolution time-lapse video microscopic study. J Neurosci 7:1928-1934.

Erickson HP, Bourdon MA (1989) Tenascin: an extracellular matrix protein prominent in specialized embryonic tissues and tumors. Annu Rev Cell Biol 5:71-92.

Erickson HP, Iglesias JL (1984) A six-armed oligomer isolated from cell surface fibronectin preparations. Nature 311:267-269.

Faissner A, Kruse J (1990) J1/tenascin is a repulsive substrate for central nervous system neurons. Neuron 5:627-637.

Faissner A, Kruse J, Chiquet-Ehrismann R, Mackie E (1988) The high-molecular-weight $\mathrm{J} 1$ glycoproteins are immunochemically related to tenascin. Differentiation 37:104-114.

Fischer G, Künemund V, Schachner M (1986) Neurite outgrowth patterns in cerebellar microexplant cultures are affected by antibodies to the cell surface glycoprotein L1. J Neurosci 6:605-612.

Fujita S (1967) Quantitative analysis of cell proliferation and differentiation in the cortex of the postnatal mouse cerebellum. J Cell Biol 32:277-288.

Fujita S, Shimida M, Nakamura T (1967) ${ }^{3} \mathrm{H}$-thymidine autoradiographic studies on the cell proliferation and differentiation in the external and the internal granular layers of the mouse cerebellum. $\mathbf{J}$ Comp Neurol 128:191-208.

Gatchalian CL, Schachner M, Sanes JR (1989) Fibroblasts that proliferate near denervated synaptic sites in skeletal muscle synthesize the adhesive molecules tenascin (J1), N-CAM, fibronectin, and a heparan sulfate proteoglycan. J Cell Biol 108:1873-1890.

Grumet M, Hoffman S, Crossin KL, Edelman GM (1985) Cytotactin, an extracellular matrix protein of neural and non-neural tissues that mediates glia-neuron interaction. Proc Natl Acad Sci USA 82:80758079.

Halfter W, Chiquet-Ehrismann R, Tucker RP (1989) The effect of tenascin and embryonic basal lamina on the behavior and morphology of neural crest cells in vitro. Dev Biol 132:14-25.

Hatten ME, Liem RKH, Mason CA (1984) Two forms of cerebellar glia cells interact differentially with neurons in vitro. J Cell Biol 98: 193-204.

Hekmat A, Bitter-Suermann D, Schachner M (1990) Immunohistological localization of the highly polysialylated form of the neural cell adhesion molecule (N-CAM) during development of the murine cerebellar cortex. J Comp Neurol 291:457-467.

Hoffman S, Friedlander DR, Chuong C-M, Grumet M, Edelman GM (1986) Differential contributions of Ng-CAM and N-CAM to cell adhesion in different neural regions. J Cell Biol 103:145-158.

Hoffman S, Crossin KL, Edelman GM (1988) Molecular forms, binding functions, and developmental expression patterns of cytotactin and cytotactin-binding proteoglycan, an interactive pair of extracellular matrix molecules. J Cell Biol 106:519-532.
Jacobson M (1978) Developmental neurobiology. London: Plenum. Jessell TM (1988) Adhesion molecules and the hierarchy of neural development. Neuron 1:3-13.

Jhaveri S, Erzurumlu RS, Crossin KL (1991) Barrel construction in rodent neocortex: role of thalamic afferents versus extracellular matrix molecules. Proc Natl Acad Sci USA 88:4489-4493.

Jones FS, Hoffman S, Cunningham BA, Edelman GM (1989) A detailed structural model of cytotactin: protein homologies, alternative RNA splicing, and binding regions. Proc Natl Acad Sci USA 86:19051909.

Keilhauer G, Faissner A, Schachner M (1985) Differential inhibition of neurone-neurone, neurone-astrocyte and astrocyte-astrocyte adhesion by L1, L2 and N-CAM antibodies. Nature 316:728-730.

Kruse J, Keilhauer G, Faissner A, Timpl R, Schachner M (1985) The $\mathrm{J} 1$ glycoprotein - a novel nervous system cell adhesion molecule of the L2/HNK-1 family. Nature 316:146-148.

Laemmli UK (1970) Cleavage of structural proteins during the assembly of the head of bacteriophage T4. Nature 227:680-685.

Larramendi LMH (1969) Analysis of synaptogenesis in the cerebellum of the mouse. In: Neurobiology of cerebellar evolution and development (Llinás R, ed), pp 803-843. Chicago: American Medical Association.

Lindner J, Rathjen FG, Schachner M (1983) L1 mono- and polyclonal antibodies modify cell migration in early postnatal mouse cerebellum. Nature 305:427-430.

Lindner J, Zinser G, Werz W, Goridis C, Bizzini B, Schachner M (1986) Experimental modification of postnatal cerebellar granule cell migration in vitro. Brain Res 377:298-304.

Lochter A, Vaughan L, Kaplony A, Prochiantz A, Schachner M, Faissner A (1991) $\mathrm{J} 1 /$ tenascin in substrate-bound and soluble form displays contrary effects on neurite outgrowth. J Cell Biol 113:1159-1171.

Lowry OH, Rosebrough NJ, Farr AL, Randall RJ (1951) Protein measurement with the Folin phenol reagent. J Biol Chem 193:265275.

Lund RD (1978) Development and plasticity of the brain. New York: Oxford UP

Mackie EJ, Tucker RP, Halfter W, Chiquet-Ehrismann R, Epperlein HH (1988) The distribution of tenascin coincides with pathways of neural crest migration. Development 102:237-250.

Maniatis T, Fritsch EF, Sambrook J (1982) Molecular cloning-a laboratory manual. Cold Spring Harbor, NY: Cold Spring Harbor Laboratory.

Martini R, Schachner M (1986) Immunoelectron microscopic localization of neural cell adhesion molecules (L1, N-CAM, and MAG) and their shared carbohydrate epitope and myelin basic protein in developing sciatic nerve. J Cell Biol 103:2439-2448.

Martini R, Schachner M, Faissner A (1990) Enhanced expression of the extracellular matrix molecule J1/tenascin in the regenerating adult mouse sciatic nerve. J Neurocytol 19:601-616.

Miale I, Sidman RL (1961) An autoradiographic analysis of histogenesis in the mouse cerebellar cortex. Exp Neurol 4:277-296.

Mugnaini E, Forstronen PF (1967) Ultrastructural studies on the cerebellar histogenesis. I. Differentiation of granule cells and development of glomeruli in the chick embryo. Z Zellforsch Mikrosk Anat $77: 115-143$

Neugebauer KM, Tomaselli KJ, Lilien J, Reichardt LF (1988) N-cadherin, NCAM, and integrins promote retinal neurite outgrowth on astrocytes in vitro. J Cell Biol 107:1177-1189.

Pagliusi SR, Schachner M, Seeburg PH, Shivers BD (1989) The adhesion molecule on glia (AMOG) is widely expressed by astrocytes in developing and adult mouse brain. Eur J Neurosci 2:471-480.

Palay SL, Chan-Palay V (1974) Cerebellar cortex. Cytology and organization. Berlin: Springer.

Persohn E, Schachner M (1987) Immunoelectron microscopic localization of the neural cell adhesion molecules L1 and N-CAM during postnatal development of the mouse cerebellum. J Cell Biol 105:569576.

Prieto AL, Jones FS, Cunningham BA, Crossin KL, Edelman GM (1990) Localization during development of alternatively spliced forms of cytotactin mRNA by in situ hybridization. J Cell Biol 111:685-698.

Purves D, Lichtman JW (1985) Principles of neural development. Sunderland, MA: Sinauer.

Rakic P (1971) Neuron-glia relationship during granule cell migration in developing cerebellar cortex. A Golgi and electronmicroscopic study in Macacus rhesus. J Comp Neurol 141:283-312.

Rathjen FG, Schachner M (1984) Immunocytological and biochemical 
characterization of a new neuronal cell surface component ( $L 1$ antigen) which is involved in cell adhesion. EMBO J 3:1-10.

Rathjen FG, Wolff JM, Frank R, Bonhoeffer F, Rutishauser U (1987) Membrane glycoproteins involved in neurite fasciculation. J Cell Biol 103:343-353.

Reynolds R, Wilkin GP (1988) Development of macroglial cells in rat cerebellum. II. An in situ immunohistochemical study of oligodendroglial lineage from precursor to mature myelinating cell. Development 102:409-425.

Saad B, Constam DB, Ortmann R, Moos M, Fontana A, Schachner M (1991) Astrocyte-derived TGF- $\beta 2$ and NGF differentially regulate neural recognition molecule expression by cultured astrocytes. J Cell Biol 115:473-484.

Sanes JR, Schachner M, Covault J (1986) Expression of several adhesive macromolecules (NCAM, L1, J1, NILE, uvomorulin, laminin, fibronectin and heparan sulfate proteoglycan) in embryonic, adult, and denervated adult skeletal muscles. J Cell Biol 102:420-431.

Sanes JR, Covault J, Gatchalian CL, Hunter DD, Laskowski MB, Merlie JP (1990) Regulation of synaptogenesis in adult skeletal muscle. In: Morphoregulatory molecules (Edelman GM, Cunningham BA, Thiery JP, eds), pp 401-420. Chichester: Wiley.

Schachner M, Antonicek H, Fahrig T, Faissner A, Fischer G, Künemund V, Martini R, Meyer A, Persohn E, Pollerberg E, Probstmeier R, Sadoul K, Sadoul R, Seilheimer B, Thor G (1990) Families of neural cell adhesion molecules. In: Morphoregulatory molecules (Edelman GM, Cunningham BA, Thiery JP, eds), pp 443-468. Chichester: Wiley.

Seilheimer B, Schachner M (1988) Studies of adhesion molecules mediating interactions between cells of peripheral nervous system indicate a major role for $\mathrm{Ll}$ in mediating sensory neuron growth on Schwann cells in culture. J Cell Biol 107:341-351.

Smith GM, Rutishauser U, Silver J, Miller RH (1990) Maturation of astrocytes in vitro alters the extent and molecular basis on neurite outgrowth. Dev Biol 138:377-390.
Spring J, Beck K, Chiquet-Ehrismann R (1989) Two contrary functions of tenascin: dissection of the active sites by recombinant tenascin fragments. Cell 59:325-334.

Steindler DA, Cooper NGF, Faissner A, Schachner M (1989a) Boundaries defined by adhesion molecules during development of the cerebral cortex: the $\mathrm{J} 1 /$ tenascin glycoprotein in the mouse somatosensory cortical barrel field. Dev Biol 131:243-260.

Steindler DA, Faissner A, Schachner M (1989b) Brain "cordones": transient boundaries of glia and adhesion molecules that define developing functional units. Com Dev Neurobiol 1:29-60.

Stern CD, Norris WE, Bronner-Fraser M, Carlson GJ, Faissner A, Keynes RJ, Schachner M (1989) J1/tenascin-related molecules are not responsible for the segmented pattern of neural crest cells or motor axons in the chick embryo. Development 107:309-319.

Tacke R, Moos M, Teplow DB, Früh K, Scherer H, Bach A, Schachner $M$ (1987) Identification of cDNA clones of the mouse neural cell adhesion molecule L1. Neurosci Lett 82:89-94.

Tan S-S, Crossin KL, Hoffman S, Edelman GM (1987) Asymmetric expression in somites of cytotactin and its proteoglycan ligand is correlated with neural crest cell distribution. Proc Natl Acad Sci USA 84:7977-7981.

Tsukamoto T, Kusakabe M, Saga Y (1991) In situ hybridization with non-radioactive digoxigenin-11-UTP-labeled cRNA probes: localization of developmentally regulated mouse tenascin mRNAs. Int J Dev Biol 35:25-32.

Wehrle B, Chiquet M (1990) Tenascin is accumulated along developing peripheral nerves and allows neurite outgrowth in vilro. Development 110:401-415.

Weller A, Beck S, Ekblom P (1991) Amino acid sequence of mouse tenascin and differential expression of two tenascin isoforms during embryogenesis. J Cell Biol 112:355-362. 